NBER WORKING PAPER SERIES

\title{
THE LEVEL AND COMPOSITION OF CONSUMPTION OVER THE BUSINESS CYCLE: THE ROLE OF “QUASI-FIXED” EXPENDITURES
}

\author{
Kerwin Kofi Charles \\ Melvin Stephens, Jr. \\ Working Paper 12388 \\ http://www.nber.org/papers/w12388
NATIONAL BUREAU OF ECONOMIC RESEARCH
1050 Massachusetts Avenue
Cambridge, MA 02138
July 2006

This paper was prepared for the National Poverty Center project, "Working and Poor: How Economic and Policy Changes are Affecting Low-Wage Workers." We would like to thank Rebecca Blank, Sheldon Danziger, Robert Hall, Robert Schoeni, James Sullivan, and especially Christopher Jencks for helpful comments and observations. Yaa Akosi Antwi provided excellent research assistance. The views expressed herein are those of the author(s) and do not necessarily reflect the views of the National Bureau of Economic Research.

(C2006 by Kerwin Kofi Charles and Melvin Stephens, Jr. All rights reserved. Short sections of text, not to exceed two paragraphs, may be quoted without explicit permission provided that full credit, including (C) notice, is given to the source. 
The Level and Composition of Consumption Over the Business Cycle: The Role of "QuasiFixed" Expenditures

Kerwin Kofi Charles and Melvin Stephens, Jr.

NBER Working Paper No. 12388

July 2006

JEL No. D12, E21, E24

\begin{abstract}
We study how the level and composition of household expenditures changes over the business cycle for households at different positions in the income distribution. Using data from the Consumer Expenditure Survey, we find that transitory, state-specific increases in unemployment causes lower income groups to lower their total expenditure outlays, contrary to the prediction of the textbook account of consumption behavior. In addition, in bad economic times these groups raise the share of their total outlays devoted to relative fixed outlays like home or car payments. These adjustments are primarily concentrated among reductions in outlays devoted to entertainment and personal care expenditures. We find no similar effects for households at higher positions in the income distribution. It is difficult to attribute these differences across households to differences in credit constraints, both because the specific results for credit holdings are imprecisely estimated and because income losses experienced by higher SES households are so small that there is, for them, little need to adjust consumption.
\end{abstract}

\author{
Kerwin Kofi Charles \\ Harris School \\ University of Chicago \\ 1155 East 60th Street \\ Chicago, IL. 60637 \\ and NBER \\ kcharles@uchicago.edu \\ Melvin Stephens \\ H. John Heinz III School of Public Policy and Mana \\ Carnegie Mellon University \\ 5000 Forbes Avenue \\ Pittsburgh, PA 15213 \\ and NBER \\ mstep@cmu.edu
}




\section{Introduction}

The years from 1988 to 2000 spanned large changes in the macro-economy. There was a sharp economic downturn in the early nineteen-nineties, a long and robust expansion in the mid to later parts of the decade, and an economic slowdown at decade's end. ${ }^{1}$ How did these macro-economic fluctuations affect the well-being of American families? Were the effects similar across households at different positions in the income distribution, or were households with low or modest income affected disproportionately? In this paper we investigate how recent macro-economic changes, and the changes in income and unemployment associated with them, affected the level and composition of households' consumption, with particular attention paid to the differential changes across the income distribution.

While the overwhelming majority of the literature studying household economic well-being has focused on income, wages or earnings as the outcomes of interest, many recent authors, studying a variety of research questions, have focused on household consumption - usually measured by expenditures devoted to a given bundle of consumption items (Cutler and Katz 1991, Krueger and Perri 2002). Among the things that recommend this focus on consumption is its connection to theory. Economists model individuals' utility, not as direct function of their income, but rather as a function of the consumption and leisure their income finances. The modern theory of consumption behavior yields a sharp set of predictions about how consumption ought to respond to changes in different aspects of consumers' constraint sets, and thus helps frame empirical analysis by creating a null against which actual consumption behavior can be measured.

Ever since the seminal work of Friedman (1957), Ando and Modigliani (1963), and Modigliani and Brumberg (1954), economists have argued that consumption in every period is determined by consumers' "permanent income" - roughly the mean of the various income streams received over periods and states of the world. The lifecycle/permanent income hypothesis $(\mathrm{LCH} / \mathrm{PIH})$ posits that a rational consumer solves the dynamic consumption problem by "smoothing” consumption across periods. That is,

\footnotetext{
${ }^{1}$ According to the National Bureau of Economic Research, the business cycle peaked in July 1990, hit a trough in March 1991, and did not reach another peak until March 2001. See http://www.nber.org/cycles.html/.
} 
he saves when income is high by consuming less than his income, and either borrows against future income or uses previously acquired savings when income is low. These actions ensure that the marginal (expected) utility of consumption is equalized across periods, and that consumption is unaffected by period to period transitory variation in income. $^{2}$

But the theoretical LCH/PIH prediction of consumption smoothing across periods and states of the world depends crucially on whether particular textbook assumptions are satisfied. For example, the incorporation of uncertainty or risk aversion can significantly weaken this sharp prediction. Both these things are likely to bedevil the real-world consumer. An even more important real-world departure from what is usually explicitly assumed in the standard model is that capital markets are not, in fact, perfect. More, these markets are probably especially imperfect for particular types of households. Anecdotal evidence suggests that many consumers cannot easily borrow against their future income when their current income is low. Thus, even if it is granted that all households can save in periods of high income simply by consuming less than their income in the period, adverse transitory income shocks might nonetheless lower consumption for persons whose savings are low, or who are unable to secure loans in bad times. In the real world, imperfect capital markets might cause the level of consumption to change with current changes in economic fortunes, relative to the presumed smoothlife cycle path.

Current consumption and current income may be linked for another reason, which has been much less emphasized in the literature. Whereas the theoretical literature typically speaks of “consumption” as a single, undifferentiated entity, a household's consumption encompasses a widely different set of goods. One way in which these goods differ is in the ease with which expenditure outlays devoted to them can be adjusted. Indeed, in the short run, expenditures on particular classes of consumption items are effectively fixed - or at least inflexible downwards without incurring some substantially penalty. To see how differences in the ease with which expenditures can be adjusted, especially in an environment with imperfect capital markets, might cause

\footnotetext{
${ }^{2}$ While this smoothing behavior is typically ascribed only to non-durable consumption, the theoretical result also extends to durable goods (Mankiw 1982). Moreover, households not only act to smooth their stocks of durable goods, but they will also smooth their durable good expenditures.
} 
income shocks to sub-optimally alter the composition if not the level of consumption, consider the following scenario.

Suppose that individuals live for two periods, and that in each period they consume two goods - say "trips to the movies" and "housing”. These goods are financed out of income flows received in the two periods. The LCH/PIH says that utilitymaximizing agents should equalize the (expected) marginal utility of a particular consumption good over time. Otherwise, lifetime utility could be increased by shifting consumption out of one period in which marginal utility is low and into one where it is high. Utility maximization also implies that the marginal utility of the two goods should be equalized at any given time. We have already discussed how negative shocks to income may cause consumption to be sub-optimally adjusted downward if capital markets are imperfect. Notice that because it is, in general, very difficult to lower housing payments, such reductions in total consumption expenditure should come disproportionately out of movie attendance - a consumption item that is relatively easy to adjust. As a result, adverse income shocks might cause the marginal utility of movie attendance to be sub-optimally high relative to that of housing. In general, if capital markets are not perfect, and if items in the consumption bundle are relatively inflexible, regular, and unavoidable, the consumption of other, more flexible aspects of consumption is forced to be lower than the consumer would optimally prefer. In this paper, we refer to these difficult to adjust or avoid types of expenditures as "quasi-fixed expenditure" (QFE). ${ }^{3}$

The preceding discussion forms the foundation of the empirical work in this paper. Like the other authors in this volume, we are interested in the effect of the business cycle changes during the 1990s on the well-being of U.S. households, and

\footnotetext{
${ }^{3}$ Browning and Crossley (2004) present a model in which credit constrained households have differential responses to income shocks across goods with differing degrees of durability. In their framework, a credit constrained household that suffers a small negative transitory income shock will cut back primarily on durable expenditures but very little on non-durable expenditures. Intuitively, since households derive utility from their stocks of durable goods which are in part carried over from the previous period, these relatively larger changes in durable expenditures do not correspond to nearly as dramatic changes in utility (See also the empirical results in Dynarski and Gruber 1997). Browning and Crossley note that if durable purchases are irreversible, then large negative income shocks will lead to large changes in non-durable consumption since households will be unable to lower their accumulated durable stocks to help smooth non-durable consumption. Analogously for the current paper, one can view quasi-fixed expenditures as durable goods with a positive irreversibility constraint which leads households to undergo larger changes in non-durable consumption than they would in the absence of the constraint.
} 
especially on those of lower income. Our organizing assumptions are: (a) that capital markets are less than perfect, especially for low income households, and (b) that an important part of a household's expenditure outlays are quasi-fixed expenditures (QSE), in the sense described above. ${ }^{4}$ Given these assumptions, we expect recent macroeconomic changes to have generated several effects, which we formally test for in the data.

First, contrary to the basic LCH/PIH, changes in the macro-economy and the income changes associated with them should have changed the level of households' consumption (as measured by their expenditures). Second, business cycle changes should have changed the composition of consumption bundles, with the largest changes occurring for low income families. Specifically, we expect that the share of households' total expenditure outlays devoted to quasi-fixed consumption items should have risen in bad times and (perhaps) fallen in good, with these effects most pronounced for those at the bottom of the income distribution. A corollary is that the share of household expenditure devoted to easily adjustable non-durable consumption should have moved pro-cyclically, especially for the low income. Third, since the principal means by which households likely make short-term credit adjustments is the use of instruments like store or commercial credit cards, we expect relatively larger percentage changes in total noncollateralized debt during bad periods for the less constrained high-income than we do among lower income families. The paper finds very strong support for the first two propositions. Curiously, the evidence about debt holdings is much less convincing.

The remainder of the paper proceeds as follows. In the next section we describe Consumer Expenditure Study (CEX) data used in the paper. Section 3 discusses how we sort households by their income position, and presents some summary results about average changes in total expenditure, total quasi-fixed expenditure over the business cycle for different types of households. In Section 4 we outline the regression framework and describe how we measure different types of non-durable expenditures in the analysis. Formal regression results are presented in Section 5 and Section 6 concludes.

\section{Data}

\footnotetext{
${ }^{4}$ Jappelli (1990) finds that roughly 20 percent of U.S. households are credit constrained.
} 


\section{CEX Overview}

This study uses data from the Consumer Expenditure Survey (CEX) Interview Survey (United States Department of Labor, various years). The CEX is an on-going, rotating, panel dataset in which consumer units (households) are interviewed up to five times, at intervals of three months between interviews. In any given calendar quarter, approximately five thousand consumer units (CUs) are interviewed, with some CUs beginning their participation in the survey and others completing their fifth (final) interview. The initial interview collects household demographic information which is updated during subsequent interviews to reflect any changes in household composition. The second through fifth interviews each collect CU expenditure information for the three calendar months immediately preceding the interview.

The CEX also collects information regarding labor force activities and government transfer receipt for each CU member age fourteen and above. Labor force information includes data on earned income, annual works worked, and usual weekly hours. Data on transfer program participation and benefit amounts includes Social Security, Supplemental Security Income, and Unemployment Insurance. Income and benefit amounts correspond to the twelve months prior to the interview date. Following the advice of the BLS staff, federal, state, and FICA (Social Security) taxes for each CU are calculated by using the NBER's TAXSIM program (Feenberg and Coutts 1993). All dollar figures are deflated to the January 2000 CPI-U using information on the interview month and year.

Unfortunately, because labor force and transfer receipt information is collected only during the second and fifth interviews, changes in labor force and transfer payment outcomes can only be ascertained between these interviews. It is difficult to interpret these changes in the data because the questions put to respondents concern the preceding twelve months, while there are only nine months between these two surveys. A further limitation is that rather than asking a labor force participation question similar to those found in other studies, such as whether the respondent is disabled, retired or unemployed, labor force status information is only acquired for those who did not work at all during that past twelve months. These issues greatly complicate examining the relationship between changes in expenditures and changes in labor force and/or transfer payment 
outcomes within households. As such, we limit our analysis here to examining differences across households by focusing only on the data reported by households in their second interviews. Although limiting the sample to just one interview per CU results in a large loss of expenditure data, we are greatly limited by the fact that the labor market and transfer information is not collected as frequently as the expenditure data. ${ }^{5}$

\section{Expenditure Information in CEX}

The primary data collection undertaken in the CEX involves expenditures on a wide variety of items. The CEX Interview Survey collects information on all expenditures except housekeeping supplies, personal care products, and nonprescription drugs. However, since these items comprise a fairly small share of total expenditures, the BLS believes that the Interview Survey captures up to 95 percent of total expenditures. ${ }^{6}$ For this study, total expenditures consist of two parts: outlays on what we term "quasifixed” and all other expenditures. The CEX's Monthly Expenditure Files (MTAB) contain information on all new spending. ${ }^{7}$ Thus, since loan payments represent payments on previously purchased items rather than new spending, no information on loan payments is contained in the MTAB files. Loan payments on mortgages or on vehicles two of the main components of "quasi-fixed" expenditures - are not to be found on these files, and are calculated from another source, which we describe below. On the other hand, some of expenditures on the MTAB do represent outlays on QFE's. Vehicle lease payments, rent for homes and apartments, and insurance payments are the main examples of this sort. To compute total non-fixed payments, we sum all quarterly expenditures on

\footnotetext{
${ }^{5}$ Given our emphasis on quasi-fixed expenditures, of which housing expenditures are a major component, the ability to examine changes in these payments would be useful. For households that take out a new mortgage, purchase a new vehicle, or pay off an existing loan, we can track these changes in the CEX. However, since the CEX tracks residences and not individual households, we can not follow changes from being a renter to becoming a homeowner and vice versa. A similar scheme of sampling residences is used by the Current Population Survey.

${ }^{6}$ See United States Department of Labor (Various Years) for more details. The codebook for the Interview Survey notes that between five to fifteen percent of total expenditures is accounted for by the categories not collected by the Interview Survey.

${ }^{7}$ The MTAB files include information on the month of expenditure. Some expenditures in these files do not perfectly align with the three month reference period prior to the interview month. Following previous studies, expenditures are allocated to the appropriate reference period. In addition, pension contributions and cash contributions are not included in our analysis.
} 
the MTAB files, and then subtract out the measures which we characterize as quasifixed. ${ }^{8}$

The CEX collects a wide array of information concerning payments we characterize as quasi-fixed outlays. Housing expenditures represent our main example of expenditures that cannot be easily adjusted. For home-owning households, a large number of questions are asked pertaining to the financing of the home. For each house owned by the CU, detailed information is collected for each mortgage that the household holds and is made available on the public use files beginning in 1988. Included in this information is the amount of the monthly payment for each mortgage. Beginning in 1991, the CEX also collected information specifically focusing on home equity loans as well as home equity lines of credit. The amount of the regular payments for each home equity loan is collected as well as the amount of the last payment for the home equity line of credit. Households are asked whether their mortgage payments and payments on home equity loans include other payments such as property taxes, property insurance, and mortgage guarantee insurance. Since these expenses should be difficult to adjust, we include them in our measure of quasi-fixed housing payments. ${ }^{9}$ Finally, the CEX also collects information on rent payments for CU renting their residence.

Expenditures on vehicles are the second class of QFE in the paper. Payment information for all vehicles is covered by the CEX including cars, trucks, motorcycles, and boats. A variety of data is collected for each vehicle including information on the vehicle model, the purchase date, and, if one exists, the vehicle loan or lease. Most important for our study, the regular payment amount for each loan and lease is collected.

In the empirical work, our main measure of quasi-fixed expenditures combines payments on residences (mortgages, home equity loans and lines of credit, rent, property taxes, and homeowner fees) and payments on vehicles (vehicle loan and lease payments). Some other forms of expenditures, such as utility payments and insurance payments might be considered “quasi-fixed”, but we study expenditures on this category of outlays

\footnotetext{
${ }^{8}$ Specifically, rent payments, vehicle lease payments, property taxes, homeowner fees (such as condominium fees), the interest portion of payments on home and vehicle loans, and payments on homeowner's, renter's, and vehicle insurance plans are considered fixed payments that appear on the MTAB files. In some of our analysis, we will also consider utility payments to be fixed payments.

${ }^{9}$ The CEX also collects information on property taxes and fees such as condominium fees. These expenses are included as part of fixed housing payments.
} 
separately, for reasons discussed below. ${ }^{10}$ Total expenditures are, of course, the sum of the particular quasi-fixed and all other expenditure outlays coded in the CEX. ${ }^{11}$

The third outcome discussed in the Introduction is a measure of a household's non-collateralized debt. This is the debt households hold on things like department store or bank credit cards. We treat these obligations as a separate item for a couple of reasons. On the one hand, these obligations may too large to be completely ignored, and are the major mechanism by which households might adjust their consumption on other items. On the other hand, even if households run up substantial credit card debt, their outlays on them can be quite minimal. We thus use a measure of non-collateralized debt which measures not how much people pay to service this type of debt each year, but rather how much they report owing on this type of debt as of the interview month. ${ }^{12}$

Some consumer units were deleted because of missing data. The primary reason for deleting CUs is when they are deemed by the BLS to have incomplete income data (20 percent of the sample). This designation is, in general, based upon the reporting of values for major sources of income such as wages and salaries, self-employment income, and Social Security income. These households are not used because the BLS sets all income data to zero (even for categories in which data is reported) for this set of CUs. ${ }^{13}$ In addition, we exclude households with missing or top-coded data for home or vehicle loan information or for rental payments. ${ }^{14}$

\section{Basic Summary Statistics}

Table 1 presents the summary statistics for the three main outcomes variables, over all households and for the years 1988-2000. As mentioned above, all dollar figures are in January 2000 dollars. Over the thirteen years studied, quarterly household total

\footnotetext{
${ }^{10}$ Research on the impact of utility expenditure fluctuations due to weather changes finds that higher utility payments reduce food as well as other non-durable consumption (Bhattacharya, DeLeire, Haider, and Currie 2003; Cullen, Friedberg, and Wolfram 2004).

${ }^{11}$ In the previous literature, total expenditures are defined as the sum of expenditures on the MTAB files with some exceptions such as pension and cash contributions (Parker 1999; Souleles 1999). Our definitions includes these expenditures as well as the fixed housing and vehicle payments that do not appear on the MTAB files but are found elsewhere in the CEX data.

${ }^{12}$ The fifth interview of the CEX contains information on the total amount of finance charges and late fees paid in the last year. However, information on monthly payment amounts on non-collateralized debt is not available.

${ }^{13}$ See United States Department of Labor (Various Years) for more details.

${ }^{14}$ This last restriction affects five percent of the observations.
} 
expenditures averaged $\$ 8243$. The standard deviation around this expenditure was quite large, at $\$ 7236$. The last three entries in the column show the $10^{\text {th }}$, median and $90^{\text {th }}$ percentile of the total expenditure distribution. These numbers show that the distribution of total expenditures was quite uneven; half of all households had quarterly expenditures of less than $\$ 6400$ or less, while households with in the top 10 percent of expenditures spent more than $\$ 15,700$ a quarter.

The second column shows the means for the main measure of QFE used in the paper. This index is the sum of all payments on home and vehicle payments. Expenditures devoted to the items averaged \$2142 a quarter across all households and years, with a standard deviation that was larger than this mean at \$2776. If anything, the distribution for QFE is even more skewed that for total expenditures, with the $10^{\text {th }}$, median and $90^{\text {th }}$ percentile being a $\$ 125, \$ 1580$ and $\$ 4717$, respectively. Occasionally, we will use another measure of QFE. This measure is the sum of home and vehicle payments, and payments made to insurance. Like home and vehicle payments, insurance payments are a commitment generally made prior to the current period, and are difficult to adjust by varying use. Utility payments might also have a quasi-fixed character, but we look at results for this outcome separately for reasons discussed below. The table indicates that quarterly outlays to the alternative quasi-fixed items of home, vehicles and insurance payments averaged \$2600 a quarter across all households and years, on average. Adding insurance payments does little to change the uneven nature of the QFE distribution: the $10^{\text {th }}$, median and $90^{\text {th }}$ percentiles of the distribution are $\$ 439$, $\$ 1985$, and \$5456, respectively.

The final column in the table shows the non-collateralized debt held as of the interview month by households across all the years studied was $\$ 2633$. The standard deviation for more than four times the mean, at $\$ 11,953$. As the remainder of the table illustrates, the distribution of credit card and store card debt (the principal components of non-collateralized debt) over the period studied was very much right skewed; high debt households held dramatically more debt than did other households.

Figure 1 presents the average in each year of quarterly after-tax income, quarterly total expenditure, the two quasi-fixed expenditures measures, and non-collateralized debt owed. The figure shows that across all years studied, average total expenditure and 
average quarterly income across all household closely track each other, with reported expenditures slightly exceeding income in most years. ${ }^{15}$ The income numbers are of special interest as it is presumably changes in this variable over the course of the business cycle that gives rise to the behavioral responses of interest. There is some evidence of average income tracking the business cycle, but the pattern in these average numbers is certainly not striking.

Figure 1 shows that average total expenditures across all households averaged around slightly above \$8,000 in 2000 dollars. From a high of just under \$8600 in 1989, average total expenditures declined slightly to a low of \$8,000 in 1993 and are relatively constant at about $\$ 250$ higher over the succeeding years. The figure shows that quasifixed expenditures are quite constant, on average, over the years studied. Quarterly outlays on payments related to households' home and cars were around \$2,000 in each year studied. When insurance payments are added the measure of QFE, average payments to this type of expenditure were about \$400, and quite flat over time.

The patterns for average total non-collateral debt owed show much greater variation over time. In particular, outstanding debt rises somewhat before 1990, up to a maximum of around $\$ 3,000$. Over the first three years of the 1990s, debt owed fell by close to $\$ 1,000$. Average outstanding debt then rose by about $\$ 1,000$ over the next several years, reaching the late-1980s levels by 1996. In the final four years studied, debt outstanding again declined - although in these years the average decline was only about half as large as that during the early 1990s.

Somewhat surprisingly, we find that both income and total expenditures - while exhibiting cyclical fluctuations - do not show any evidence of an upward trend over this period. The lack of an increase in the CEX expenditure data during the 1990s while the personal consumption expenditures component of the National Income and Product Accounts increased has been noted by other researchers (Attanasio, Battistin, and Ichimura 2004). For our main empirical investigation, we are primarily interested in the variation in expenditure and income over the business cycle, specifically the degree to which these measures vary with state-level employment fluctuations. As such, the

\footnotetext{
${ }^{15} \mathrm{CEX}$ income is an annual income measure. We divide this computed annual number by 4 for presentation in this graph.
} 
decline in these measures in the early 1990s as well as the subsequent increases in the latter part of the decade suggests that there is indeed interesting variation over the business cycle to examine, the lack of an upward trend notwithstanding.

\section{Classifying Households by Income Position}

We are interested in the effect of macro-economic changes on the consumption patterns of households at different positions in the income distribution. Ideally, we would like to sort households by their levels of permanent income and assess how macroeconomic variation differentially affects them. Unfortunately, we do not observe permanent income. Our strategy in what follows will thus to be sort households by their positions in the CEX national income distribution. One consequence of this choice is that households are stratified by their position in the distribution of a variable which is itself determined by business cycle changes. We doubt that this is a serious problem since, as we discuss below, the variation in the regression analysis is within-state, idiosyncratic variation - something unlikely to appreciably affect how a household compares to all households in the country. Nevertheless, to raise confidence that our results do indeed reflect differences across persons with different levels of lifetime resources, we will also present results in which households are distinguished by the education of the household head, the race of the household, and whether or not the household is headed by a single mother.

Figures 2a shows the after-tax mean of annual household income across all the households used in the analysis, and by income quartile. On average, household income was just above $\$ 30,000$ in each year. Average incomes for the households in the bottom three quartiles of the national income distribution exhibit very little variation over time. In each year, after-tax incomes for these three groups diverge by between $\$ 1,000$ and $\$ 1,200$, with the incomes for the lowest quartile averaging slightly less than $\$ 9,000$. The figure reflects the skewness of the overall after-tax income distribution; households in the highest quartile of the income distribution have incomes that are, on average, double those of households in the third quartile. 
As mentioned, we will also show results in which groups are distinguished along other dimensions likely correlated with their levels of lifetime resources. Figure $2 \mathrm{~b}$ shows mean after-tax income for subgroups in the different categories whose permanent incomes we would expect to be relatively low. The graph plots average after-tax income for African-Americans, single mothers, and high school dropouts. For ease of comparability, we have kept the scale of the graphs on Figures $2 \mathrm{a}$ and $2 \mathrm{~b}$ the same so that the reader can readily see compare incomes for these groups to the overall income distribution. The figure shows that all of these groups have incomes below the mean for all households, with the possible exception of single mothers. Since the very loweducated, racial minorities and single mothers are precisely the persons whose permanent income we expect to be especially low, these results further justify our focus on a household's quantile position in the national income distribution as the measure of lifetime or permanent income. As noted, we also present results in which the focus is on variation at the by household race, family-type and schooling.

Next, we briefly show how the key outcomes of interest in the paper changed over time for different sorts of households. Figures 3-5 summarize changes in the four measures for persons at different positions in the income distribution. Figure 3 shows that such changes to total expenditure as occurred over the years seems to have been driven by changes in the expenditure outlays of households in the highest quartile of the income distribution. For example, in 1990, total quarterly expenditures for this group of households were just over $\$ 14,800$. During the first three years of the 1990s, expenditures fell for this group by almost $\$ 1,500$ a quarter. In the mid-1990s, expenditures rose again, and then declined and stabilized, at close to the levels observed in the late 1980s. By contrast, for the lowest income American households, total expenditures were almost perfectly flat at $\$ 4,000$ though all of the years.

Figures 4a and 4b show changes in average QFE outlays over the business cycle for households at different points in the income distribution. The figure shows that, apart from a decline for the highest income households between 1992 and 1993, these outlays were relatively flat over time for each type of household, and from year to year in much the same manner for each group. 
The patterns for non-collateralized debt outstanding depicted in Figure 5 show that most of the changes in the mean over time were driven by changes in the highest income households. In particular, the strong U-shaped pattern in average debt holdings over the recession of the early nineteen nineties and recovery later in the decade was due almost exclusively to changes in the debt holdings of the high income. For those at the bottom of the income distribution, debt holding seemed to have changed only very modestly over the years studied.

These figures hint at a very modest pro-cyclical dimension to total expenditures, and a weaker one for quasi-fixed expenditures. It must be emphasized that these patterns are merely suggestive. Changes in the various outcomes are not purged of any secular effects that might be coincidentally correlated with business cycle changes and driving the relationships indicated. For example, a national expansion in credit which happened to coincide with national economic downturns would exaggerate the apparent extent to which households used credit when times were bad. Nor do any of the results shown control for systematic sources of variation for each of the outcomes. Life-cycle considerations are an important example of these. In addition, regional variation possibly due to differences in economic fluctuations across industries is another such factor. The figures shown are effectively aggregate level results, as they relate national unemployment to national expenditure and debt. The causal relationship of interest would seem be the relationship between the economic conditions in a state on the consumption expenditure and debt holding patterns of the people who live there. An aggregate level analysis cannot effectively get at this question, nor can it account for unobserved state-specific factors that affect expenditures.

Below, we use regression analysis to study the connection between local (statelevel) economic conditions and the level and composition of consumption within the state. Apart from state level controls, our regression specifications will also control for age of household, and other systematic effects.

\section{Regression Estimates of Effect of Unemployment Variation and Changes in Level and Composition of Expenditures}


In this section, we formally assess how recent macro-economic changes affected the level and composition of consumption expenditures and debt using a series of regressions. Of special interest to us is whether expenditures on quasi-fixed expenditure outlays "crowd-out" other forms of expenditures during economic times, and how the various effects differ for households at different positions in the income distribution.

\section{Framework}

We estimate regressions of the form:

$$
y_{i t}=\theta_{s}+\theta_{t}+\beta_{1} X_{i t}+\beta_{2} U_{s t}+\beta_{3} I Q_{i}+\beta_{4}\left(U_{s t} * I Q_{i}\right)+\varepsilon_{i t}
$$

In (1) $y_{i t}$ is either total expenditure, total debt owed, or share or fraction of total spending devoted to particular expenditure items. The variables $\theta_{s}$ and $\theta_{t}$ are vectors of state and time fixed effects. The vector $X_{i t}$ contains controls for like the age of household, household size, race and family structure. $U_{s t}$ measures the unemployment rate in the state at time $t . \quad I Q_{i}$ are indicator variables denoting the household's position in the income distribution. We will mainly measure that position by an indicator denoting the income quartile to which the household belongs, but will also show results where income position is measured by the education of the household head, the race of the household and whether it is headed by a single mother.

Because they contain state fixed effects, the regressions (1) measure how, for households in a given state, higher unemployment in that state in a particular year relative to the state's time mean, affects expenditure and debt holdings. The inclusion of the time fixed effects ensures that the estimates are purged of the possible contamination attributable to unobserved secular trends that affects all groups equally. Because there might also be secular effects specific to particular groups, such as the very low income, or those with low levels of schooling, we also add group-specific trends to the various regressions.

We are chiefly interested in three sets of coefficients from the regressions: $\beta_{2}$ through $\beta_{4}$. The coefficient $\beta_{2}$ measures how the particular outcome variable changes, 
on average across all households, with changes in the business cycle. $\beta_{3}$ measures systematic differences across income groups in expenditure and debt holding for the different income and education groups. The $\beta_{4}$ on the interaction term measures whether macro-economic changes produce different effects on expenditures and debt holdings for the various income groups. If a particular income (or education, race, or family structure) group's response to macro-economic changes is the same as that of the excluded groups (those with the lowest income or lowest education) the estimated coefficient for the particular interaction term will be zero.

In some regressions, we focus on the various "ratio measures" - specifically the share of a household's total expenditure going to a particular type of expenditure. Since we also separately study results for total expenditure, it is straightforward in most cases to combine these results to determine how the level of expenditure on particular item is affected over the business cycle. For example, if total expenditure for particular groups remains constant during booms, but the share of expenditure devoted to item $x$ rises, then if follows the total spending on good $x$ goes up. We focus on these ratios because they directly address the issue of the composition of expenditure over the business cycle (one of our chief interests).

\section{Measuring Consumption}

In our estimation of (1), we use two measures of quasi-fixed expenditures. The first combines payments on residences (mortgages, home equity loans and lines of credit, rent, property taxes, and homeowner fees) and payments on vehicles (vehicle loan and lease payments). The other adds insurance payments to this measure.

One difficultly we confront is how to measure aspects of consumption that are not the QFEs. The convention in the previous work on consumption has been to lump various "non-durable” consumption items into a single category. However, there has been considerable variation in the particular items scholars have chosen to include in their measures. To help determine which variant, if any, of the different measures that have appeared in the literature we should use in our analysis, we decided on the simple strategy of examining what the alternative measures that have appeared in the literature say about life cycle consumption patterns. If the picture one gets about lifecycle 
consumption differs markedly from one measure to the next, then it would seem appropriate to not rely on the choice of any of these measures in our analysis, but instead to focus on the specific items that make up the composite non-durable measure.

Figure 6 plots the coefficients from a series regression in which the spending measure is regression on a full vector of dummy variables for age, and on state and time fixed effects. The plotted effects show how expenditure changes over the life-cycle, relative to the excluded age 25 , netting out the effect of national variation, and the effect of anything systematic about the state in which the household member happens to be located. If over the lifecycle expenditure on non-durables remained the same, all of the plotted age effects would be zero.

Souleles (2000) uses a non-durable expenditure measure consisting of outlays on: food, alcohol, tobacco and smoking supplies, utilities, personal care, household operations (personal services and other household expenses), public transportation, gas and motor oil, apparel, health expenditures, education, and reading materials. Lusardi (1996) uses a measure of non-durable expenditure called "strictly non-durable consumption" which is the same as the Souleles measure, except that it subtracts off education, health, apparel, and reading material. Lusardi's measure attempts to capture expenditures that are truly non-durable over a quarterly interval. Parker (1999), Hsieh (2003), and Stephens (2003) all study how predictable changes in income affect consumption behavior. These papers measure non-durable expenditures as the sum of food, alcohol, textiles, small appliances, miscellaneous equipment, apparel, entertainment, personal care, reading, tobacco/smoking, public transportation, and gas and motor oil. Their non-durable measure does not include health, education or utilities as do the Souleles and Lusardi measures, but does include entertainment unlike those other measures.

Figure 6 shows that the differences over the lifecycle in the fraction of outlays devoted to non-durable consumption as measured by these three measures. The figure shows that the Lusardi measure's share of total expenditure is the same as the Souleles measure until age 55. Thereafter, its share of total expenditure is basically flat, while that of the Souleles measure rises dramatically. The Parker/Hsieh/Stephens measure exhibits a very different pattern than either of the other two measures. In particular, the share of 
expenditure devoted to this non-durable measure consistently falls below age-25 levels once household reach age 60, and then fall in further in each successive year.

What accounts for the difference across the various measures? In Figure 7 we present results similar to those in Figure 6, but for specific expenditure items. The figure presents results for health expenditures, food, utilities and outlays on expenditures on entertainment and personal care. We have drawn the graphs in Figures 6 and 7 on the same scale. From a comparison of the figures, it is clear that it is increased health spending than accounts for the difference between the Souleles and Lusardi non-durable measures. And, the pattern for utilities explains, in turn, why the Parker/Hsieh/Stephens measure diverges from the Lusardi measure.

Rather than use an aggregate non-durable measure in the analysis below, we study particular consumption items separately. The results above suggest that the obvious individual measures to focus on are: health, food, entertainment and personal care, and utilities. Looking at each of these items separately obviates the need to choose among the different non-durable measures that have appeared in the literature, and also allows us to more precisely characterize the dimensions along which households adjust the composition of their expenditures as macro-economic conditions change.

\section{Results}

Table 2a investigates how business cycle fluctuations affect households' after tax income. The first column of the table presents the relationship between state unemployment and income, in a regression with state and time fixed effects. The point estimate implies that a one percentage point increase in a state's unemployment rate lowers after tax income by about $\$ 390$, averaged across all households. In the specifications in the second and third columns, the coefficient on the unemployment rate measures how business cycle changes affect the expenditures of the excluded group households with the lowest income or schooling. ${ }^{16}$ These regressions and all others like them to follow, also control for household age, race, marital status, household size as well

\footnotetext{
${ }^{16}$ The CEX includes a variable for the household's place in the income distribution for household's that are deemed complete income reporters. Indicators for income quartile are created from this variable. The four education categories are high school dropout, high school graduate, some college, and college graduate.
} 
as differential time period effects for the specific group being investigated. ${ }^{17}$ The coefficients on the interactions terms measures how much higher or lower the response for the indicated group is relative to that of the lowest income/schooling households. The coefficient on the unemployment rate measures the impact of unemployment on the lowest income/education group.

These results show that increases in unemployment lower the incomes of households in the lowest income quartiles by relatively large and strongly statistically significant amounts, while affecting the incomes of those with higher levels of income and schooling only modest, if at all. For example, the results in column 2 suggest that each 1 percentage point change in unemployment lowers after-tax income in the lowest income quartile fall by about $\$ 450$, and lowers incomes in the third quartile by only half this amount.

Table $2 \mathrm{~b}$ does the same analysis as that in the final two columns as Table 2a, but with households distinguished by race and single mother status. On the whole, the results are consistent with our expectations. Unemployment lowers income for blacks as well as for single mothers relative to other groups.

How do these income changes over the course business cycle affect consumption? Table 3a and 3b show results for total expenditure. The layout of these Tables is exactly the same as that in Tables 2a and 2b.

The first column in Table 3a shows that a one point increase in unemployment lowers total expenditure by a modest $\$ 116$ across all households. The results in the second column show that each one point increases in unemployment lowers total expenditures for the lowest income quartile by a statistically significant $\$ 170$. The point estimates imply that a 1.9 point increase in the unemployment rate, such as that which occurred nationally between 1990 and 1992, lowered total expenditures of the lowest income households by about $\$ 324$. This represents an eight percent reduction relative to mean expenditures for this group of about $\$ 4000$ in a given year. The other point estimates in the second column suggest that there is effectively no change in total expenditures over the business cycle for households other than those at the bottom of the

\footnotetext{
${ }^{17}$ For example, when the unemployment rate is interacted with each of the quartile indicators, the specification includes differential time period effects for each quartile to capture any differential national trends across the income quartiles.
} 
income distribution. The results in the third column, in which the unemployment rate is interacted with the household's education rather than with its income position, are broadly consistent with these results.

Table 3b does the same analysis as that the last columns of Table 3a, but uses other indicators of households' income position. The first column shows unemployment has the same on total expenditure effect across all races. In the second column, by contrast, we find that single mothers sharply lower total expenditures when unemployment rises. Given the earlier results for income, which showed that both racial minorities and single mothers experience disproportionately large income losses when there is higher unemployment, the fact that the two groups respond so differently with respect to total expenditure is surprising.

The next set of regression results measure how the composition of expenditures varies over the business cycle. In these regressions, the outcomes are the share of household expenditure that is devoted to each of the indicated expenditure items. Before presenting these results, Table 4 presents the means for these share variables for over the years studied for all households, and by household income quartile. The table shows that for all households, expenditures on the quasi-fixed categories of home and vehicle payments represent about a quarter of all expenditures across households, with the share rising slightly the higher the household's income. When QFE expenditures include insurance payments, the share is about five to seven percentage points higher for every group. Outlays on food comprise about a fifth of the expenditures of the average household. Unlike QFE outlays, the importance of this item in expenditure set, following the familiar Engel's Law, falls slightly as income rises. Utilities exhibit a pattern similar that found for food expenditures. For all households, expenditures on health and outlays on entertainment and personal care each constitute about eight percent of expenditures.

Table 5a presents results for the effect of local unemployment changes on the fraction of expenditures devoted to home and vehicle payments. It has been our argument throughout that because these quasi-fixed expenditures are difficult to adjust in the short run, they constitute a larger share of total expenditures in bad times, and a smaller share if households are forced to vary total expenditures over the business cycle. Are the results consistent with this reasoning? In the first column of Table 5a, the 
estimated point estimate, which represents the mean across all households, is indeed positive and statistically significant.

In the second and third columns, the interaction terms assess how this effect varies across households defined by income quartile and schooling. Now, the coefficient on the unemployment variable measures the effect for the lowest income households. The point estimate is positive and strongly statistically significant. It suggest that a two point increase in the unemployment rate increases the fraction of expenditures going to home and car payments by about 0.016 . This represents about an eight percent increase in share of expenditures going to these quasi-fixed outlays for this group of households. The positive estimated interaction terms in the column imply that the effects for other income quartiles are smaller by statistically significant amounts from what occurs for the lowest income quartile. Indeed, since the total effect for any of these other groups is the sum of the point estimate of the unemployment variable and the relevant interaction term, the results indicate that for households other than the lowest income the share of total expenditures going to home and vehicle payments changes very little over the business cycle. The final column in the table tells a virtually identical story to that in column two: changes in the business cycle affect the share of resources devoted to quasi-fixed payments, but only for households at the bottom of the SES distribution. ${ }^{18}$

In Table $5 b$ we distinguish households by race and by single mother status. The results for single mother households are consistent with the notion that the lowest SES households spend larger fractions of their budgets on housing and vehicle payments in bad economic times. However, as with the results for total expenditure, we again find the somewhat surprising result that racial minorities are no more likely to see the share of their expenses going to these two main quasi-fixed expenditures rise with increases in unemployment even though income is observed falling for this group. It is worth noting, though, that the point estimates on the two race variables are twice the size as the main effect. It may be that the lack of power precludes any significant conclusions in these data.

\footnotetext{
${ }^{18}$ We estimate but do not present the results measuring QFE as home and vehicle payments, plus payments on insurance and/or plus utility payments. The results are quite similar to those shown in Table 5a.
} 
The results show that for some households quasi-fixed expenditures rise as a share of total expenditure outlays when the economy did poorly and rose when it did well. What types of expenditure are "crowded-out" or increased from those households" consumption bundles as a result? Table 6a examines the share of total expenditures going to the four largest items in households' non-durable expenditures: food (both eaten at home and away), health, entertainment and personal care, and utilities. The table presents results only for the main regressions in which the unemployment rate is interacted with household income quartile.

The results in Table 6a show that for health and utility expenditures, business cycle variation produce no changes in the fraction going to the consumption for any type of family. For higher income households, these results are not too surprising, since we could find only no reductions in total expenditures for them, and virtually no changes in the fraction they allocated to outlays on quasi-fixed expenses. It is reassuring, however, to observe that adjustments the lowest income households make to their consumption expenditures do not come out of these immensely important items. Nor the lowest income families adjust by altering their food consumption over the business cycle.

Table 6a shows dramatically that it is on the expenditures devoted to entertainment and personal care where the lowest income families make adjustments over the business cycle. The strongly statistically significant estimate in the first line implies that household at the bottom of the income distribution lower the share of their outlays going to things like movie and concert tickets, haircuts, televisions, radios or sound equipment in bad times, and increase them in good, by about -0.002 for each one percentage point increase in the state's unemployment rate. The other entries in the column show that the allocation of higher income households to entertainment and personal consumption over the business cycle is different in a strongly significant way to that for the lowest income. In particular, the results indicate that for every type of household except those in the bottom income quartile, entertainment's share as a fraction of total expenditure outlays does not change at all as the business cycle changes.

The results in Table $6 \mathrm{~b}$ present a picture that is by now very familiar. These results show that, on the whole, the results for other groups with low SES closely match the results when unemployment is interacted with income quartile, except for the results 
for racial minorities. Thus, for entertainment and personal care, the only category for which we find any evidence of compositional change over the business cycle, single mothers lower expenditures devoted to this item in bad times. There is no such effect for racial minority groups, despite the fact that their income losses during recessions are about the same size as those for single mothers.

Our results thus far have shown that both the level and composition of expenditure of the lowest income households appear to have been affected by the macroeconomic changes of the past decade and a half. When the economy is bad and income falls, their total expenditures fall, and the share of resources they devote to quasi-fixed payments like home and vehicle payments, rise. Further, the results suggest that low income households make these adjustments to the composition of their expenditure outlays principally by lowering their expenditure on entertainment and on personal care, rather than on things like health, utilities, or food.

What accounts for these different patterns across groups? One obvious possible answer might be that the lowest income households are more credit constrained than other income groups. Thus, rather than using credit to smooth consumption and keep the composition of consumption the same over the business cycle, they are forced to make the adjustments described above. In the final two tables in the paper - Tables 7a and 7b we examine how total non-collateralized debt owed varies over the business cycle for different groups.

On the whole, the results for debt owed are not precisely estimated. Nonetheless, the point estimates do offer some suggestive evidence that might partly explain the results we find. The results indicate that, consistent with our expectation, lower income groups do not increase their debt holdings over the business cycle, and might actually lower debt slightly. By contrast, there is weak evidence that higher income households slightly increase debt in bad times - precisely what the standard model would predict for non credit-constrained households. The results for other subgroups in Table $7 \mathrm{~b}$ are not precisely estimated but interesting nonetheless. We find weak evidence that blacks might slightly increase debt in bad times, unlike single mothers whose debt holding appear to fall slightly. This differential response with respect to debt holdings might explain why 
blacks are the only low SES group for which we find changes in neither the level nor composition of consumption expenditure over the business cycle.

\section{Conclusion}

In this paper, we have argued that because of credit market and other imperfections, transitory variations in income such as those arising from business cycle fluctuations, might cause consumption behavior to depart from the textbook standard. In particular, in bad economic times affected households might be such imperfections might caused affected households to lower total expenditure, and to increase the share of their overall consumption devoted to expenditure items like car or vehicle payments that are difficult to adjust without a cost.

We distinguish households by their position in the national income distribution, as well as by their race and whether they are headed by a single mother. Using a series of regressions in which we exploit state-specific variation over time, and in which we also control for general time effects and well as group-specific trends, we find that local variation in unemployment are generally associated with reductions in after-tax income for the lowest SES groups. We find much smaller or non-existent reductions for higher permanent income subgroups. Our results indicate that most lower-income groups lower total expenditure when state unemployment is high. There are no reductions for households higher up in the income distribution.

Changes in the composition of expenditure outlays are also concentrated among lower income groups, to the extent that they exist at all. When state unemployment rises, we find that most lower-income groups raise the fraction of their expenditure outlays devoted to what we term quasi-fixed expenditure. Interestingly, we find that the only specific non-durable consumption item on which these groups lower expenditure is for the category of entertainment and personal care. Important expenditures such as food and health do not appear to be affected.

One noteworthy departure from these patterns is that for racial minority groups. Despite the fact that their income falls when state unemployment rises, we find little evidence that they alter either their total consumption or their outlay on particular items 
over the business cycle. Precisely why these patterns exist is somewhat of a puzzle. One possible explanation, of course, is due to sampling variability. Given that many of the estimated effect are of the expected sign but imprecisely estimated, this explanation is plausible. A possible alternative explanation, however, may be the apparently different ways in which racial minorities use non-collateralized debt such as store or commercial credit cards relative to other lower income groups. All of our results for debt are noisy, but we do find suggestive evidence that blacks might increase debt holding when times are bad. In some ways, this result implies that blacks react to reductions in income associated with business cycle changes precisely as the standard model would predict: income falls, but so debt is increased to smooth the level and composition of consumption. Other lower income groups, such as high school dropouts or single mothers may not act similarly because they are more credit constrained, leading to the consumption effects we find. Another alternative explanation is that other groups do not adjust as much on other dimensions of consumption which we do not explicitly study. For example, it might be whether a family changes its living arrangements as the business cycle changes - an issue studied in this volume by Fairlie and London - might differ across various subgroups of lower income. Combining all components of adjustment in one analysis would be an interesting effort for future work. 


\section{References}

Ando, Albert and Franco Modigliani. 1963. "The Life-Cycle Hypothesis of Saving: Aggregate Implications and Tests,” American Economic Review, 53(1), 55-84.

Attanasio, Orazio P., James Banks, Costas Meghir, and Guglielmo Weber. 1995. "Humps and Bumps in Lifetime Consumption,” National Bureau of Economic Research Working Paper No.5350.

Attanasio, Orazio P., Erich Battistin, and Hidehiko Ichimura. 2004. "What Really Happened to Consumption Inequality in the US?” National Bureau of Economic Research Working Paper No.10338.

Bhattacharya, Jayanta, Thomas DeLeire, Steven J. Haider, and Janet Currie. 2003. "Heat or Eat? Cold Weather Shocks and Nutrition in Poor American Families." American Journal of Public Health, 93(7):1149-1154.

Blundell, Richard and Ian Preston. 1998. "Consumption Inequality and Income Inequality,” Quarterly Journal of Economics 113(2): 603-640.

Branch, E. Raphael. 1994. "The Consumer Expenditure Surveys: A Comparative Analysis,” Monthly Labor Review 117(12): 47-55.

Browning, Martin and Thomas F. Crossley. 2004. "Shocks, stocks and socks: smoothing consumption over a temporary income loss," Centre for Applied Microeconometrics, University of Copenhagen Working Paper 2004-05.

Julie Berry Cullen, Leora Friedberg, and Catherine Wolfram. 2004. "Consumption and Changes in Home Energy Costs: How Prevalent is the 'Heat or Eat' Decision?", University of California-Berkeley Manuscript.

Cutler, David and Larry Katz. 1991. "Macroeconomic Performance and the Disadvantaged,” Brookings Papers on Economic Activity 2: 1-74.

Dynarski, Susan and Jonathan Gruber. 2004. “Can Families Smooth Variable Earnings?” Brookings Papers on Economic Activity, 1997(1), p. 229-303.

Friedman, Milton. 1957. A Theory of the Consumption Function, Princeton, NJ: Princeton University Press.

Gourinchas, Pierre-Oliver and Jonathan A. Parker. 2002. "Consumption Over the Life Cycle,” Econometrica, 70(1):47-89.

Hsieh, Chang-Tai. 2003. "Do Consumers React to Anticipated Income Changes? Evidence from the Alaska Permanent Fund,” American Economic Review, 93(1):297405. 
Jappelli, Tullio. 1990. “Who is Credit Constrained in the U. S. Economy?” The Quarterly Journal of Economics 105(1):219-234.

Krueger, Dirk and Fabrizio Perri. 2002. "Does Income Inequality Lead to Consumption Inequality? Evidence and Theory,” National Bureau of Economic Research Working Paper No.9202.

Lusardi, Annamaria. 1996. "Permanent Income, Current Income, and Consumption: Evidence from Two Panel Data Sets,” Journal of Business and Economic Statistics, 14(1): 81-90.

Mankiw, N. Gregory. 1982. "Hall's Consumption Hypothesis and Durable Goods," Journal of Monetary Economics, 10(3), p. 417-25.

Mayer, Susan E. and Christopher Jencks. 1989. "Poverty and the Distribution of Material Hardship,” Journal of Human Resources 24(1): 88-113.

Mayer, Susan E. and Christopher Jencks. 1993. "Recent Trends in Economic Inequality in the United States: Income Versus Expenditures Versus Material Well-Being,” in Poverty and Prosperity in the USA in the Late Twentieth Century, edited by Edward N. Wolff. New York: St. Martin's Press.

Meyer, Bruce D. and James X. Sullivan. 2003. "Measuring The Well Being of the Poor Using Income and Consumption. NBER Working Paper \#9760.

Modigliani, Franco and Richard H. Brumberg. 1954. "Utility Analysis and the Consumption Function: An Interpretation of Cross-Section Data," in Kenneth K Kurihara, ed., Post-Keynesian Economics, New Brunswick, NJ: Rutgers University Press.

Parker, Jonathan A. 1999. "The Reaction of Household Consumption to Predictable Changes in Social Security Taxes,” American Economic Review, 89(4): 959-73.

Rogers, John M. and Maureen B. Gray. 1994. "CE Data: Quintiles of Income Versus Quintiles of Outlays,” Monthly Labor Review 117(12): 32-37.

Ruggles, Patricia. 1990. Drawing the Line: Alternative Poverty Measures and Their Implications for Public Policy. Washington, D.C: The Urban Institute.

Souleles, Nicholas S. 1999. "The Response of Household Consumption to Income Tax Refunds,” American Economic Review, 89(4): 947-59.

---------. 2000. “College Tuition and Household Savings and Consumption,” Journal of Public Economics, 77(2): 185-207. 
Stephens Jr., Melvin. 2003. "The Consumption Response to Predictable Changes in Discretionary Income: Evidence from the Repayment of Vehicle Loans," National Bureau of Economic Research Working Paper No.9976.

Zeldes, Stephen P. 1989. "Consumption and Liquidity Constraints: An Empirical Investigation,” Journal of Political Economy, 97(2): 305-46. 
Figure 1. Mean Across Households Quartely Income, Quarterly Total Expenditures, QFE1 (Home, Vehicles), QFE2 (Home, Vehichle, Insurance, Utilities), and Non_Collaterized Debt Owed, 1988-2000

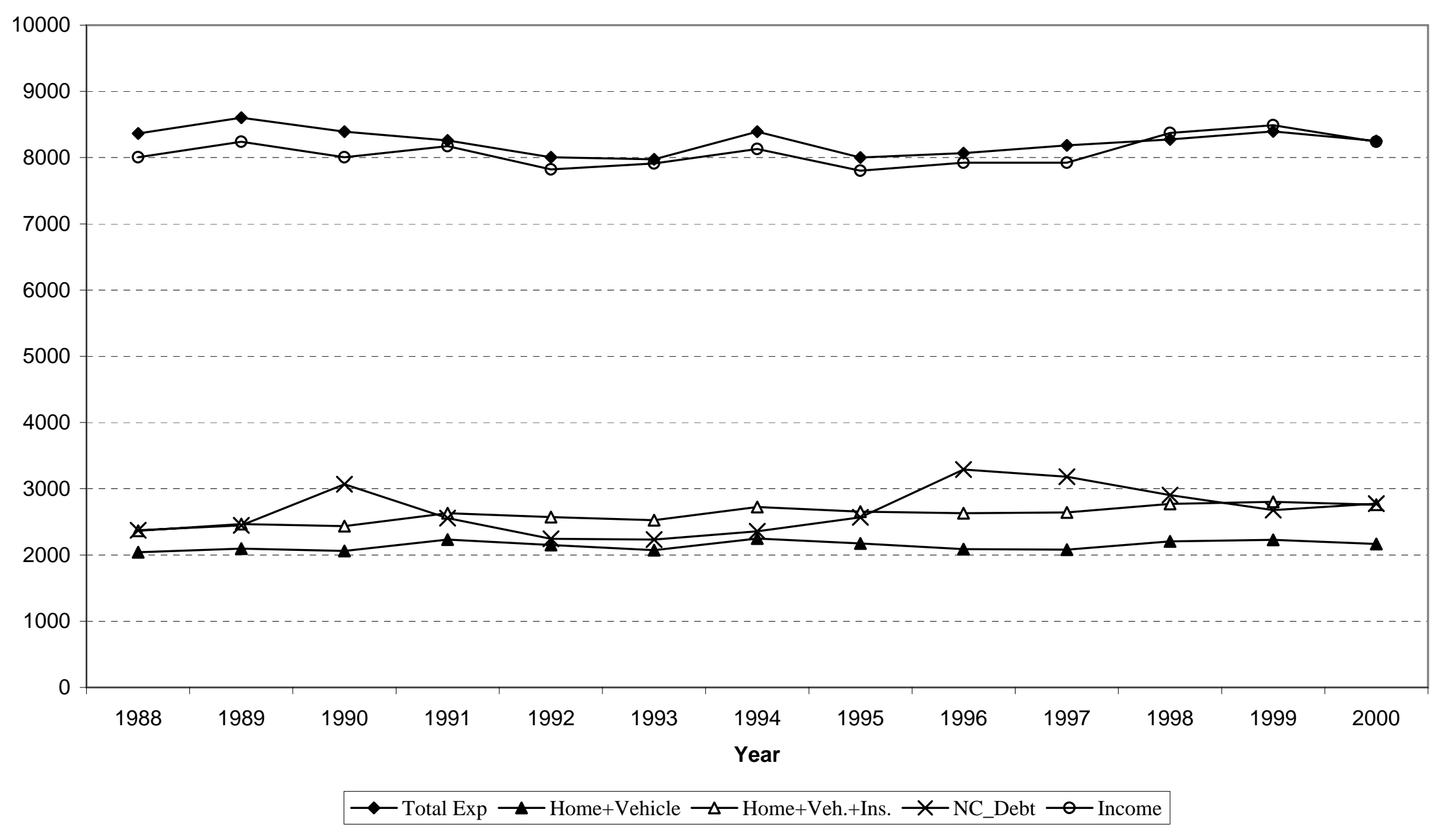



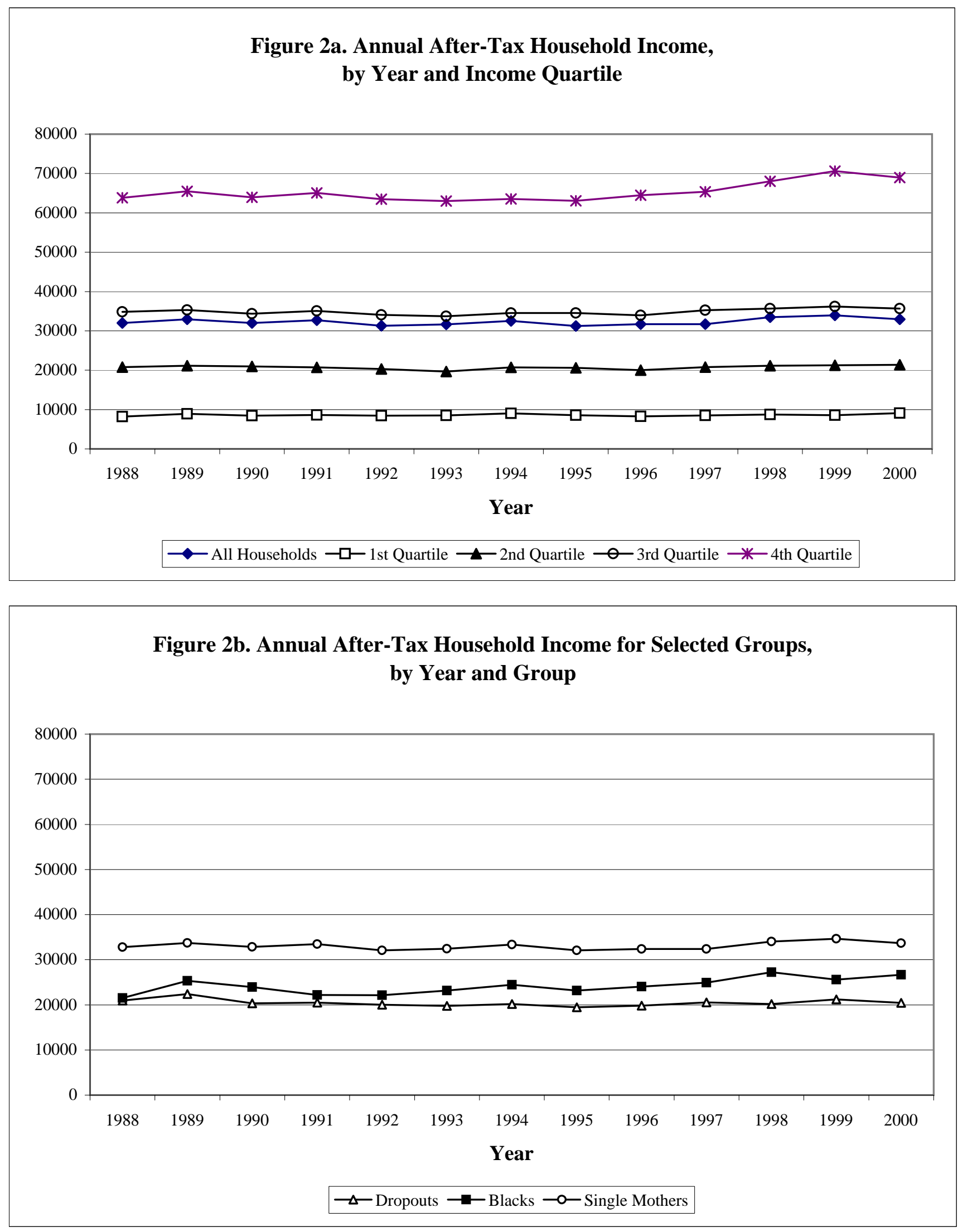
Figure 3. Total Expenditure Over Business Cycle, by Income Quartile

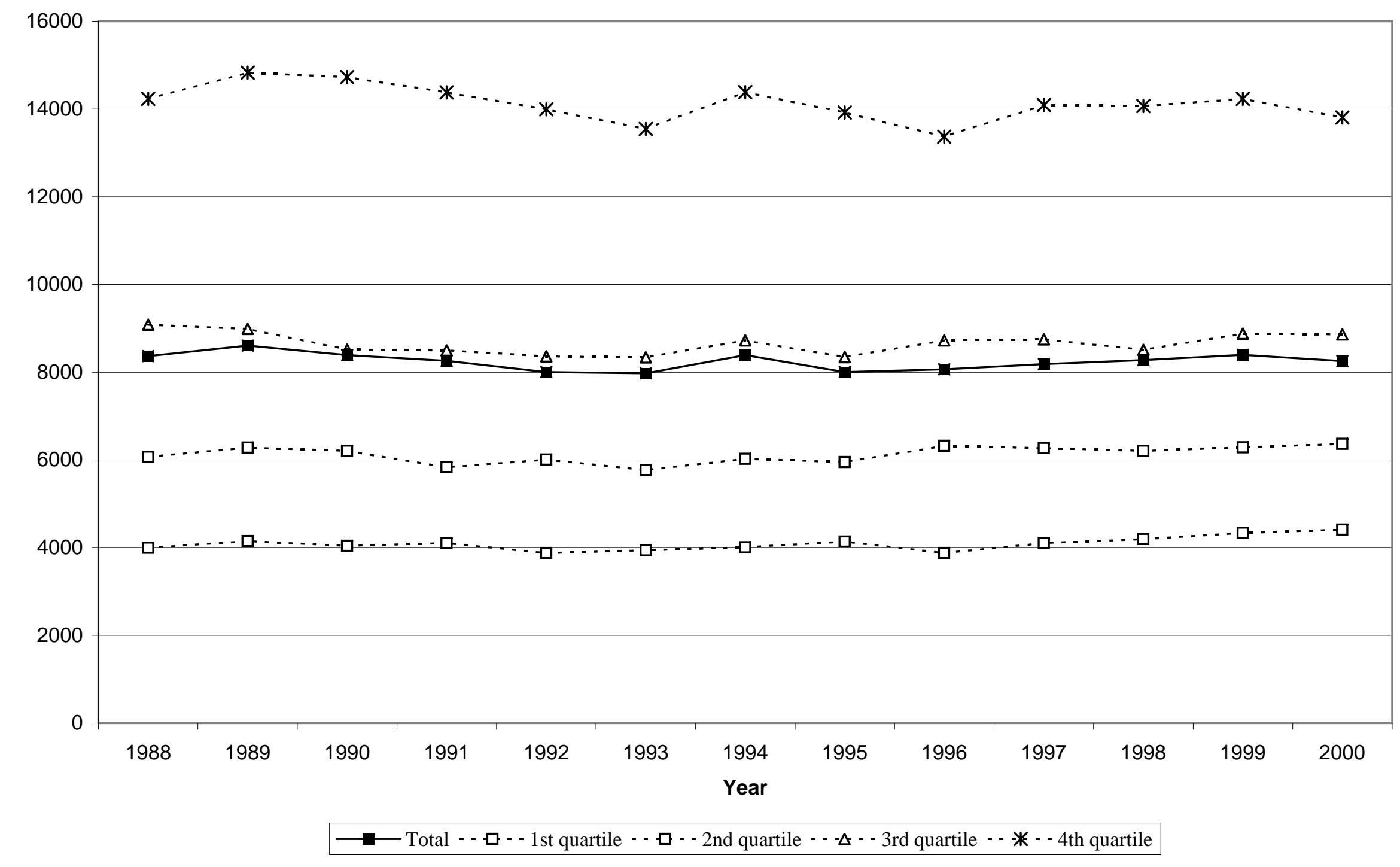


Figure 4a. Average Household Expendiures on Home and Vehicle Payments by Year and Income Quintile, 1988-2000

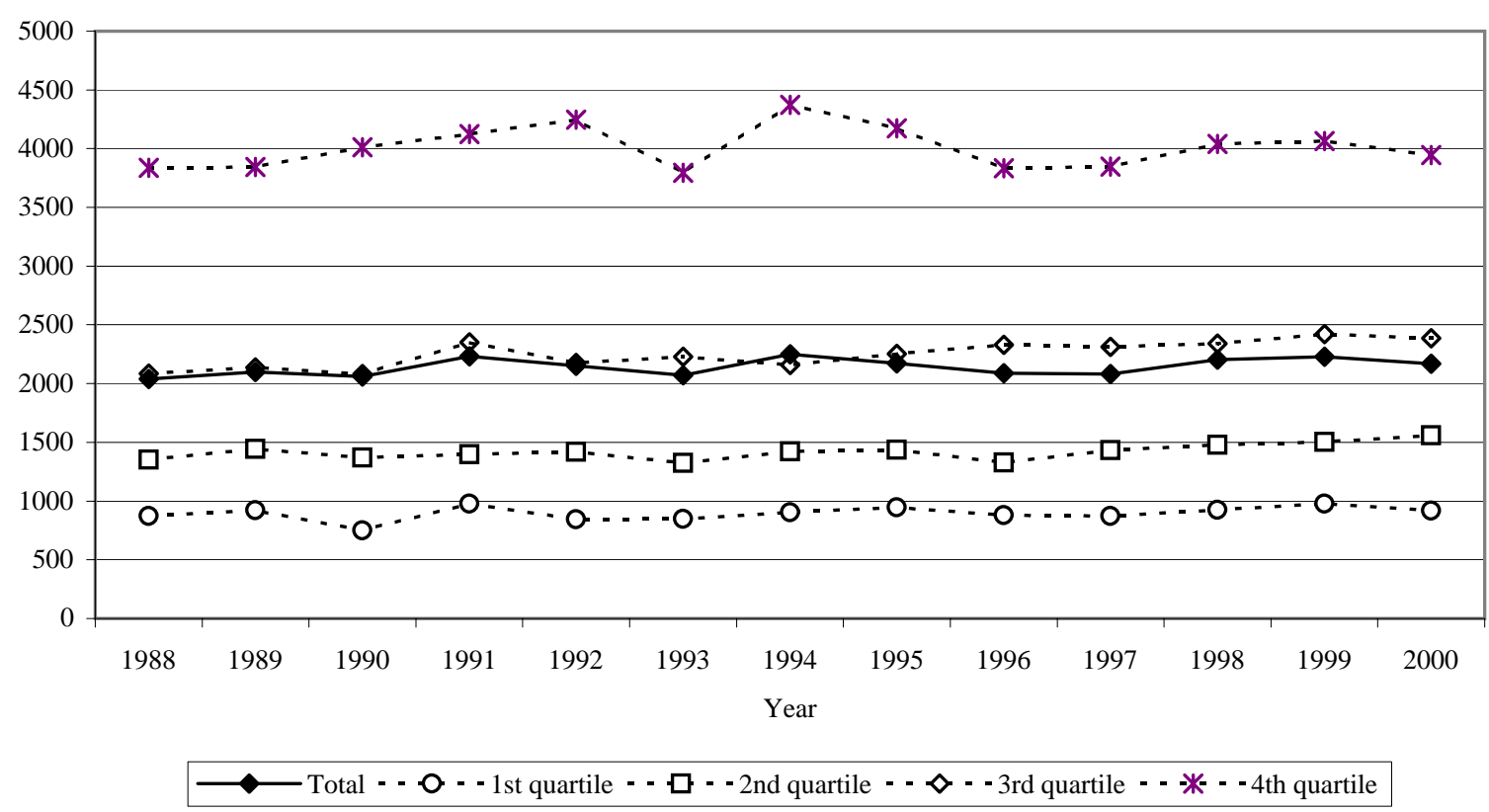

Figure 4b. Average Expenditures on Home, Vehicle, and Insurance Payments, by Year and Income Quintile, 1988-2000

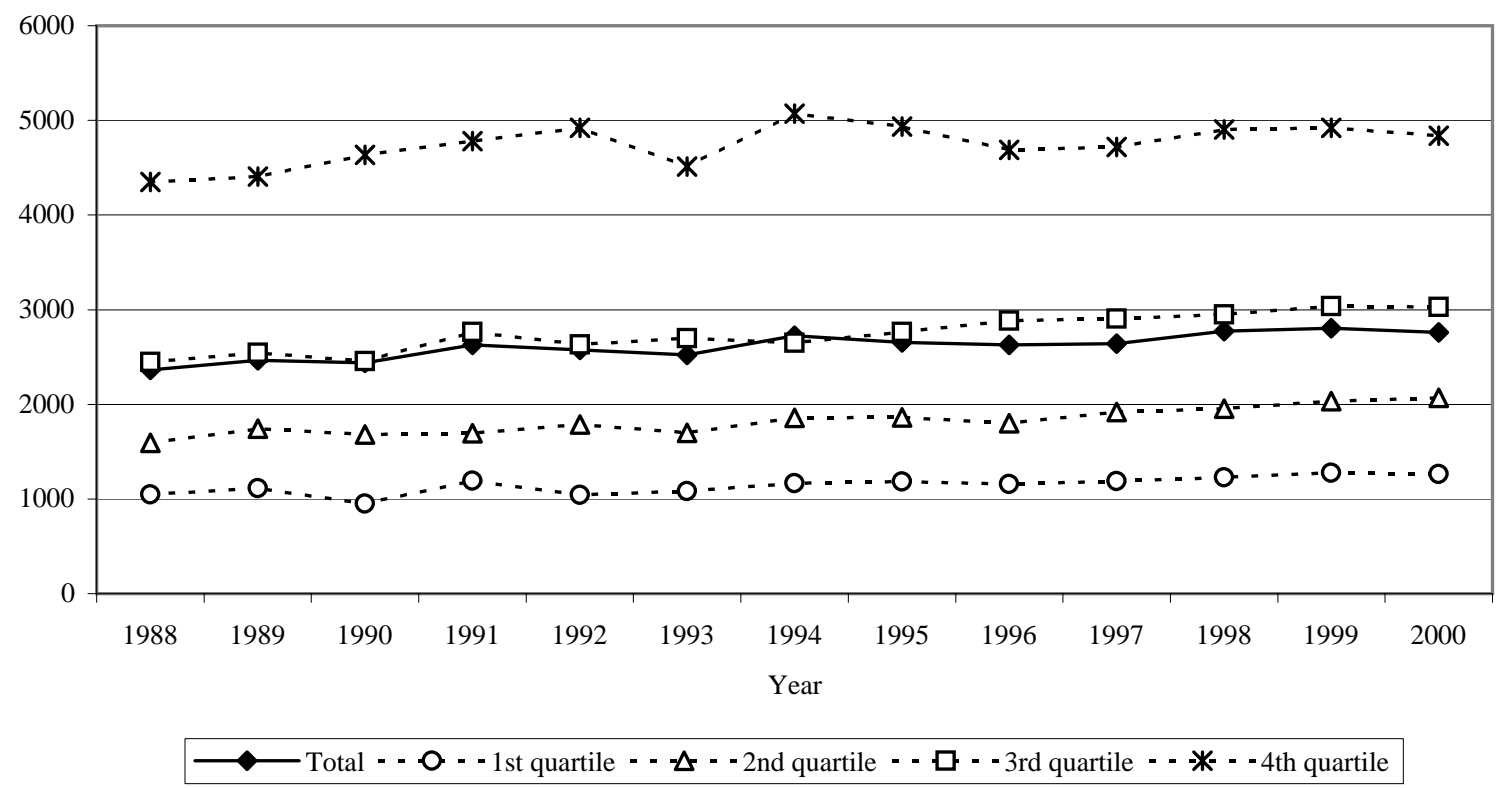


Figure 5. Total Non-Collateralized Debt Outstanding, by Year and Income Quartile

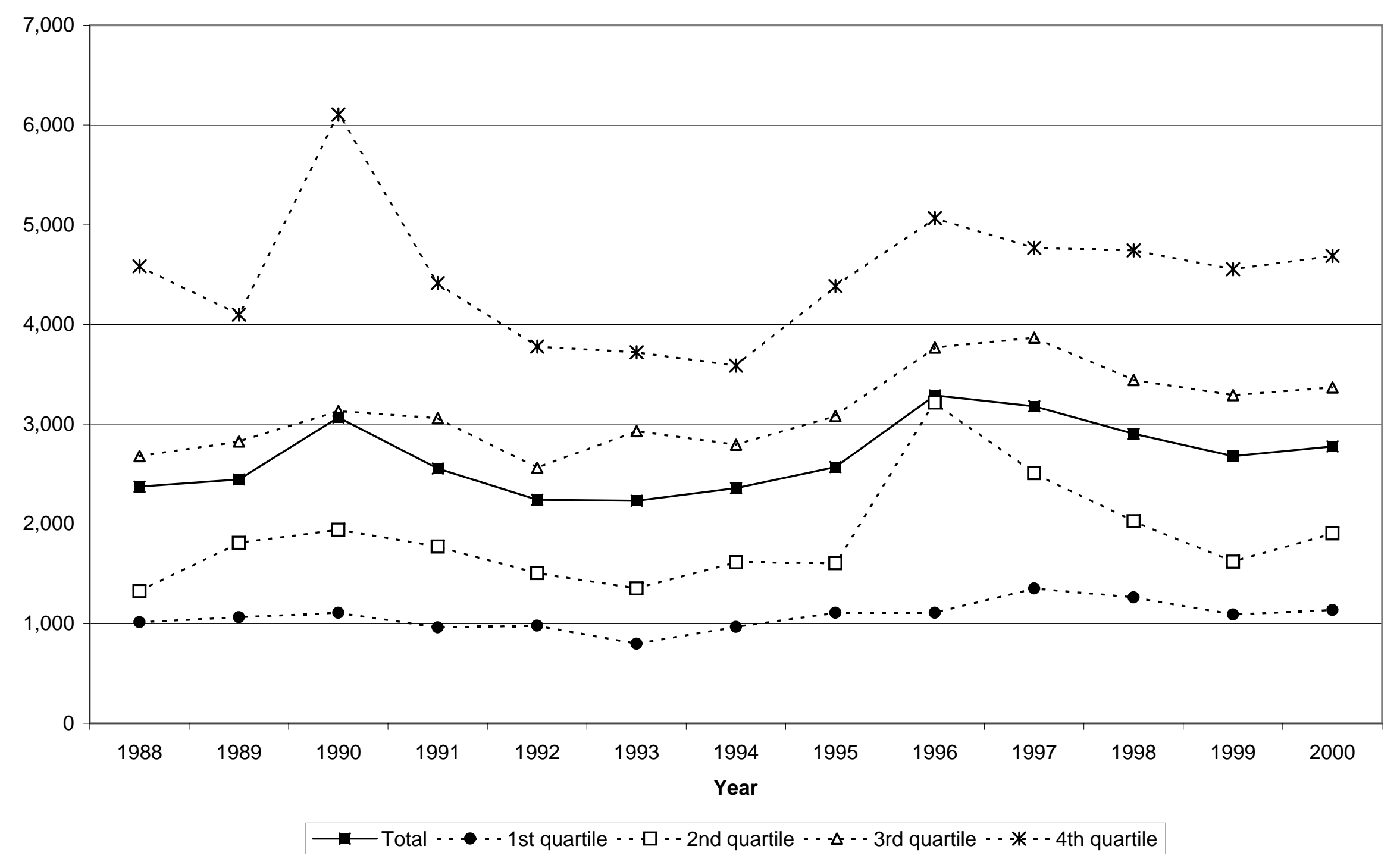


Figure 6. Share of Total Expenditure Devoted to Quasi-Fixed Expenditures and All Non-Durable Expenditures Over Life Cycle Under Alternative Definitions

Regression-Adjusted for State, Year Effects

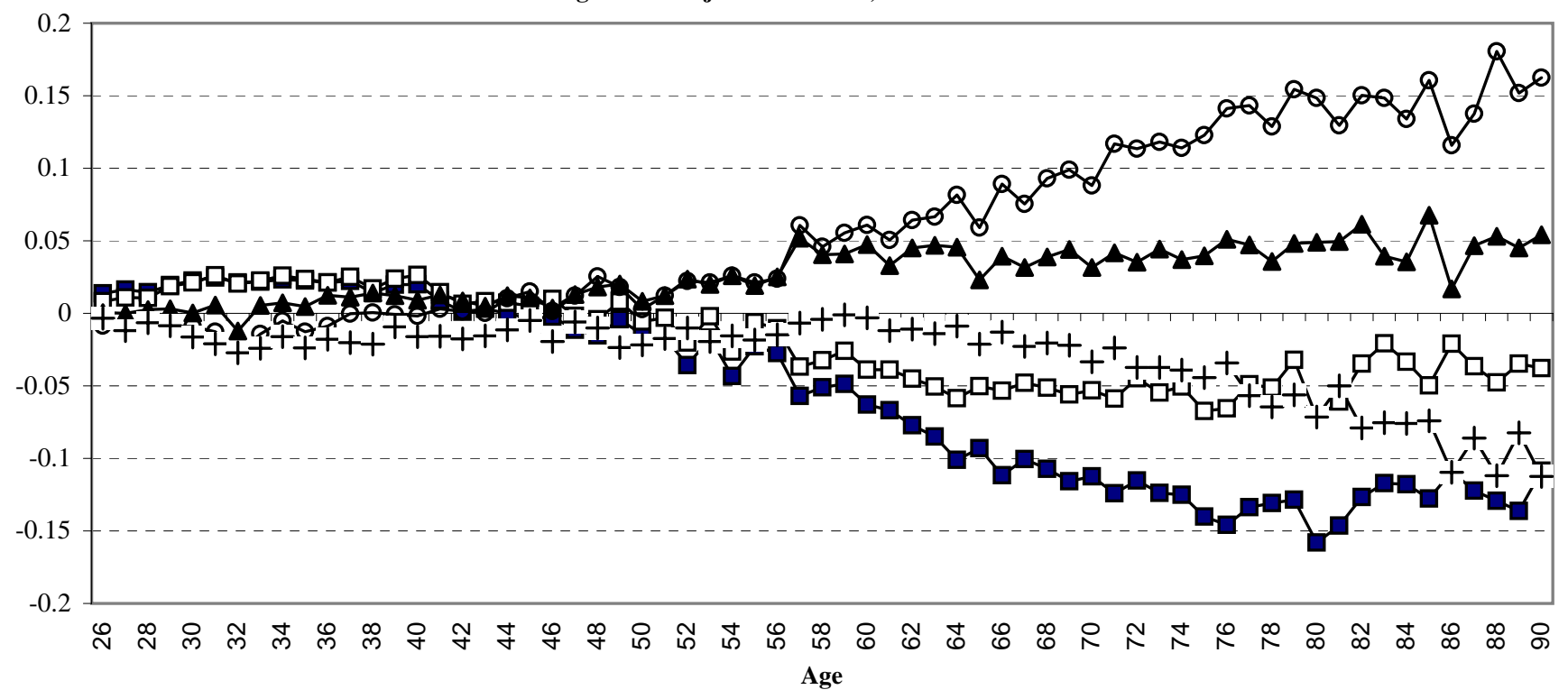

\begin{tabular}{|c|c|c|}
\hline $\begin{array}{l}\rightarrow \text {-Home + Veh. } \\
\text { - Non-Dur2: (Lusardi) }\end{array}$ & $\begin{array}{l}\text { - } \square \text {-Home + Veh. + Ins. } \\
\text { - Non-Dur3: (Parker/Hsieh/Stephens) }\end{array}$ & ○一Non-Dur1: (Souleles) \\
\hline
\end{tabular}

Figure 7. Share of Total Expenditures Devoted to Consumption Categories Over the Lifecycle Regression Adjusted For State and Time Effects

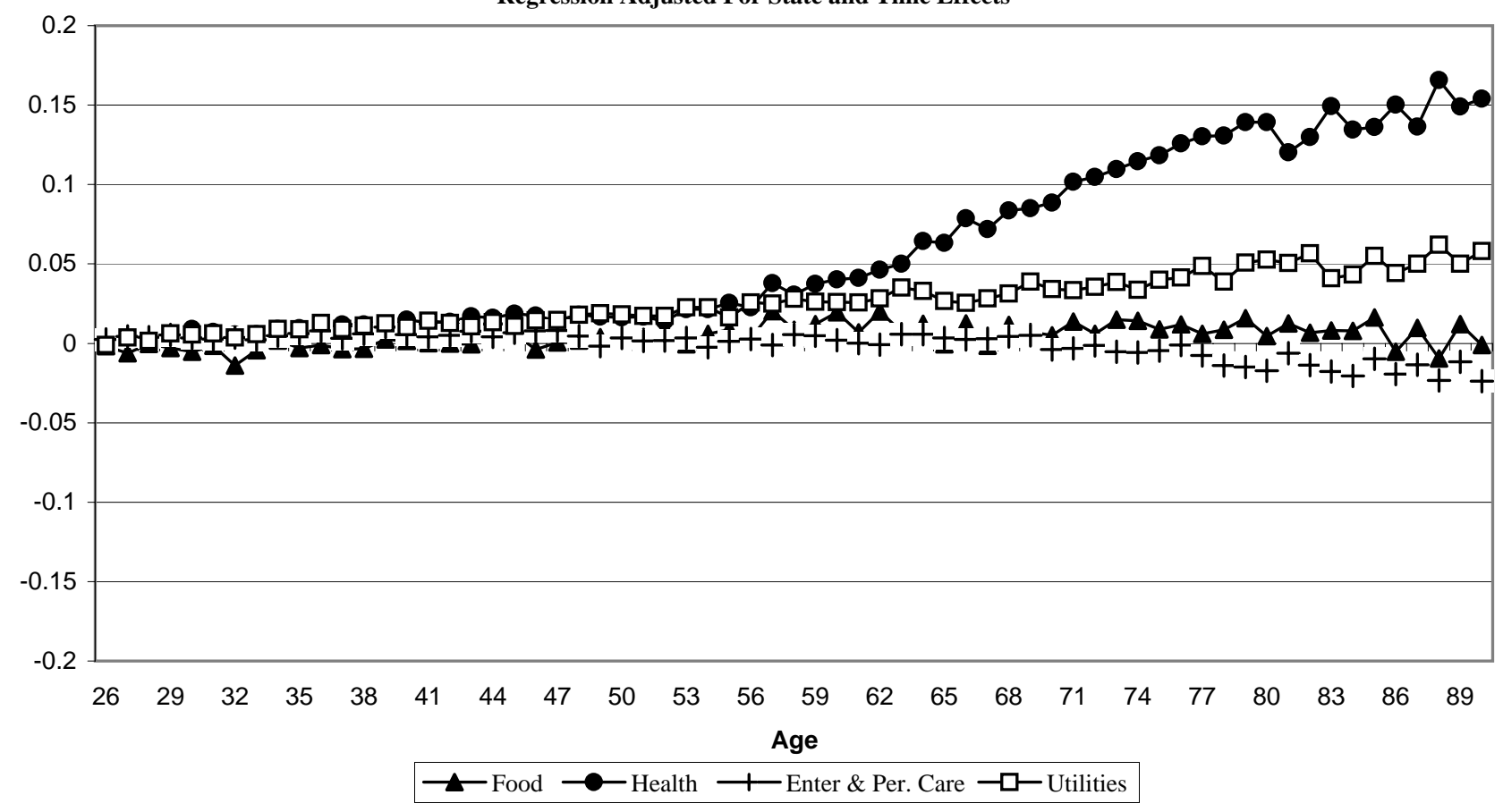




\begin{tabular}{|c|c|c|c|c|}
\hline & $\begin{array}{c}\text { Quarterly Total } \\
\text { Expenditures } \\
\end{array}$ & $\begin{array}{l}\text { Quarterly Quasi- } \\
\text { Fixed } \\
\text { Expenditures: } \\
\text { (Payments on } \\
\text { Home, Vehicles) } \\
\end{array}$ & $\begin{array}{l}\text { Quarterly Quasi- } \\
\text { Fixed Expenditures: } \\
\text { (Home, Vehicles, } \\
\text { Insurance) } \\
\end{array}$ & Debt Owed \\
\hline $\begin{array}{l}\text { Mean } \\
\text { Std. Dev. }\end{array}$ & $\begin{array}{c}8,243 \\
(7,236)\end{array}$ & $\begin{array}{c}2,142 \\
(2,776)\end{array}$ & $\begin{array}{c}2,612 \\
(2,942)\end{array}$ & $\begin{array}{c}2,633 \\
(11,953)\end{array}$ \\
\hline 10th Percentile & 2,428 & 125 & 439 & 0 \\
\hline Median & 6,398 & 1,580 & 1,985 & 140 \\
\hline 90th Percentile & 15,752 & 4,717 & 5,456 & 7,246 \\
\hline
\end{tabular}

Note: Data from the Consumer Expenditure Survey 1988-2000. See text for details. 


\begin{tabular}{|c|c|c|c|}
\hline & (1) & $(2)$ & (3) \\
\hline Unemployment Rate & $\begin{array}{l}-393.68 \\
(213.81)\end{array}$ & $\begin{array}{c}-458.98 \\
(101.10)^{* *}\end{array}$ & $\begin{array}{l}-233.80 \\
(94.58)^{*}\end{array}$ \\
\hline Unemployment Rate * Inc_Q2 & & $\begin{array}{c}58.77 \\
(70.28)\end{array}$ & \\
\hline Unemployment Rate * Inc_Q3 & & $\begin{array}{c}287.95 \\
(77.13)^{* *}\end{array}$ & \\
\hline Unemployment Rate * Inc_Q4 & & $\begin{array}{c}740.59 \\
(265.25)^{* *}\end{array}$ & \\
\hline Unemployment Rate * HS & & & $\begin{array}{c}-91.47 \\
(106.93)\end{array}$ \\
\hline Unemployment Rate * SomeColl & & & $\begin{array}{c}161.26 \\
(117.48)\end{array}$ \\
\hline Unemployment Rate * CollPlus & & & $\begin{array}{c}245.70 \\
(191.51)\end{array}$ \\
\hline Household Income Quartile & & & \\
\hline Inc_Q2 & & $\begin{array}{c}11,112.81 \\
(460.15)^{* *}\end{array}$ & $\begin{array}{c}10,769.14 \\
(109.19)^{* *}\end{array}$ \\
\hline Inc_Q3 & & $\begin{array}{c}22,583.24 \\
(610.36)^{* *}\end{array}$ & $\begin{array}{c}23,941.94 \\
(167.76)^{* *}\end{array}$ \\
\hline Inc_Q4 & & $\begin{array}{c}47,848.26 \\
(1,795.02)^{* *}\end{array}$ & $\begin{array}{c}52,716.47 \\
(572.54)^{* *}\end{array}$ \\
\hline Head's Education & & & \\
\hline High School (HS) & & $\begin{array}{c}589.98 \\
(154.22)^{* *}\end{array}$ & $\begin{array}{l}1,007.29 \\
(703.66)\end{array}$ \\
\hline Some College (SomeColl) & & $\begin{array}{c}1,498.80 \\
(178.66)^{* *}\end{array}$ & $\begin{array}{c}0.0000 \\
(0.0000)\end{array}$ \\
\hline College Plus (CollPlus) & & $\begin{array}{c}5,776.79 \\
(293.51)^{* *}\end{array}$ & $\begin{array}{c}3,863.95 \\
(1,318.07)^{* *}\end{array}$ \\
\hline Additional Controls & & & \\
\hline $\begin{array}{l}\text { State And Year Fixed Effects } \\
\text { Demographic Variables }\end{array}$ & $\begin{array}{l}\text { Yes } \\
\text { No }\end{array}$ & $\begin{array}{l}\text { Yes } \\
\text { Yes }\end{array}$ & $\begin{array}{l}\text { Yes } \\
\text { Yes }\end{array}$ \\
\hline Income Group Time Trends & No & Yes & No \\
\hline Education Group Time Trends & No & No & Yes \\
\hline Observations & 45563 & 45242 & 45242 \\
\hline R-squared & 0.02 & 0.75 & 0.75 \\
\hline
\end{tabular}

Notes: * significant at 5\%; ** significant at 1\%; The standard errors (in parentheses) allow for arbitrary correlation between observations from the same state over time; Demographic variables include age of the household head, family size, race of the household head, and marital status; See text for details 


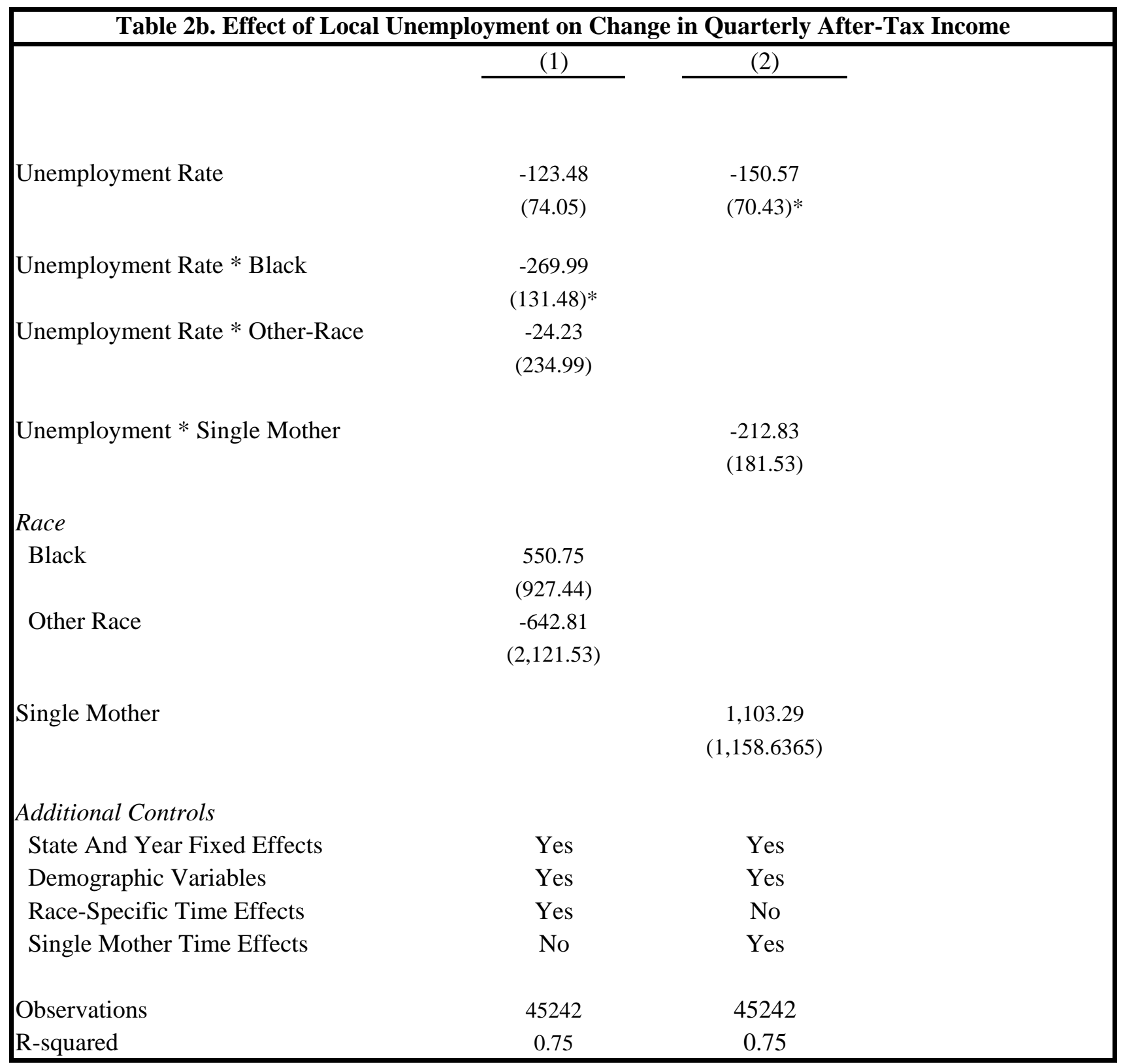

Notes: * significant at 5\%; ** significant at 1\%; The standard errors (in parentheses) allow for arbitrary correlation between observations from the same state over time; Demographic variables include age of the household head, family size, race of the household head, marital status, income group variables, and household head education group variables; See text for details 


\begin{tabular}{|c|c|c|c|}
\hline \multicolumn{4}{|c|}{ Table 3a. Effect of Local Unemployment on Household Total Expenditure } \\
\hline & $(1)$ & $(2)$ & (3) \\
\hline Unemployment Rate & $\begin{array}{c}-116.32 \\
(78.57)\end{array}$ & $\begin{array}{c}-170.82 \\
(65.17)^{*}\end{array}$ & $\begin{array}{c}-226.17 \\
(103.69)^{*}\end{array}$ \\
\hline Unemployment Rate * Inc_Q2 & & $\begin{array}{l}-59.62 \\
(54.36)\end{array}$ & \\
\hline Unemployment Rate * Inc_Q3 & & $\begin{array}{c}133.99 \\
(59.20)^{*}\end{array}$ & \\
\hline Unemployment Rate * Inc_Q4 & & $\begin{array}{c}245.99 \\
(161.00)\end{array}$ & \\
\hline Unemployment Rate * HS & & & $\begin{array}{c}66.68 \\
(103.42)\end{array}$ \\
\hline Unemployment Rate * SomeColl & & & $\begin{array}{c}216.19 \\
(146.38)\end{array}$ \\
\hline Unemployment Rate * CollPlus & & & $\begin{array}{c}270.40 \\
(119.22)^{*}\end{array}$ \\
\hline Household Income Quartile & & & \\
\hline Inc_Q2 & & $\begin{array}{c}1,369.29 \\
(412.73)^{* *}\end{array}$ & $\begin{array}{c}943.10 \\
(70.56)^{* *}\end{array}$ \\
\hline Inc_Q3 & & $\begin{array}{c}2,362.15 \\
(454.93)^{* *}\end{array}$ & $\begin{array}{c}2,514.43 \\
(131.59)^{* *}\end{array}$ \\
\hline Inc_Q4 & & $\begin{array}{c}5,765.89 \\
(1,005.77)^{* *}\end{array}$ & $\begin{array}{c}6,884.21 \\
(252.26)^{* *}\end{array}$ \\
\hline Head's Education & & & \\
\hline High School (HS) & & $\begin{array}{c}774.57 \\
(96.25)^{* *}\end{array}$ & $\begin{array}{c}673.51 \\
(665.51)\end{array}$ \\
\hline Some College (SomeColl) & & $\begin{array}{c}1,711.74 \\
(144.06)^{* *}\end{array}$ & $\begin{array}{c}0.0000 \\
(0.0000)\end{array}$ \\
\hline College Plus (CollPlus) & & $\begin{array}{c}2,962.50 \\
(134.40)^{* *}\end{array}$ & $\begin{array}{c}2,093.64 \\
(751.28)^{* *}\end{array}$ \\
\hline Additional Controls & & & \\
\hline State And Year Fixed Effects & Yes & Yes & Yes \\
\hline Demographic Variables & Yes & Yes & Yes \\
\hline Income Group Time Trends & No & Yes & No \\
\hline Education Group Time Trends & No & No & Yes \\
\hline Observations & 45563 & 45242 & 45242 \\
\hline R-squared & 0.02 & 0.31 & 0.31 \\
\hline
\end{tabular}

Notes: * significant at 5\%; ** significant at 1\%; The standard errors (in parentheses) allow for arbitrary correlation between observations from the same state over time; Demographic variables include age of the household head, family size, race of the household head, and marital status; See text for details 


\begin{tabular}{|c|c|c|}
\hline & (1) & $(2)$ \\
\hline Unemployment Rate & $\begin{array}{l}-76.99 \\
(66.94)\end{array}$ & $\begin{array}{l}-70.77 \\
(59.06)\end{array}$ \\
\hline Unemployment Rate * Black & $\begin{array}{c}0.47 \\
(86.13)\end{array}$ & \\
\hline Unemployment Rate * Other-Race & $\begin{array}{c}37.80 \\
(123.67)\end{array}$ & \\
\hline Unemployment * Single Mother & & $\begin{array}{c}-230.07 \\
(62.21)^{* *}\end{array}$ \\
\hline \multicolumn{3}{|l|}{ Race } \\
\hline Black & $\begin{array}{l}-1,544.31 \\
(610.46)^{*}\end{array}$ & \\
\hline Other Race & $\begin{array}{l}-317.80 \\
(867.50)\end{array}$ & \\
\hline Single Mother & & $\begin{array}{l}1,194.15 \\
(690.99)\end{array}$ \\
\hline \multicolumn{3}{|l|}{ Additional Controls } \\
\hline State And Year Fixed Effects & Yes & Yes \\
\hline Demographic Variables & Yes & Yes \\
\hline Race-Specific Time Effects & Yes & No \\
\hline Single Mother Time Effects & No & Yes \\
\hline Observations & 45242 & 45242 \\
\hline R-squared & 0.31 & 0.31 \\
\hline
\end{tabular}

Notes: * significant at 5\%; ** significant at 1\%; The standard errors (in parentheses) allow for arbitrary correlation between observations from the same state over time; Demographic variables include age of the household head, family size, race of the household head, marital status, income group variables, and household head education group variables; See text for details 


\begin{tabular}{|c|c|c|c|c|c|c|}
\hline & Home + Veh. & $\begin{array}{l}\text { Home + Veh } \\
\text { + Ins. }\end{array}$ & Food & Health & Entert. \& Pers. Care & Utilities \\
\hline $\begin{array}{l}\text { Mean } \\
\text { (Std. Dev.) }\end{array}$ & $\begin{array}{c}0.26 \\
(0.17)\end{array}$ & $\begin{array}{c}0.32 \\
(0.17)\end{array}$ & $\begin{array}{c}0.19 \\
(0.11)\end{array}$ & $\begin{array}{c}0.07 \\
(0.10)\end{array}$ & $\begin{array}{c}0.08 \\
(0.07)\end{array}$ & $\begin{array}{c}0.10 \\
(0.07)\end{array}$ \\
\hline $\begin{array}{l}\text { Income Qua } \\
\text { Mean } \\
\text { (Std. Dev.) }\end{array}$ & $\begin{array}{c}0.22 \\
(0.18)\end{array}$ & $\begin{array}{c}0.29 \\
(0.18)\end{array}$ & $\begin{array}{c}0.23 \\
(0.13)\end{array}$ & $\begin{array}{c}0.08 \\
(0.11)\end{array}$ & $\begin{array}{c}0.08 \\
(0.07)\end{array}$ & $\begin{array}{c}0.13 \\
(0.10)\end{array}$ \\
\hline $\begin{array}{l}\text { Income Qua } \\
\text { Mean } \\
\text { (Std. Dev.) }\end{array}$ & $\begin{array}{c}0.24 \\
(0.17)\end{array}$ & $\begin{array}{c}0.32 \\
(0.17)\end{array}$ & $\begin{array}{c}0.20 \\
(0.10)\end{array}$ & $\begin{array}{c}0.08 \\
(0.12)\end{array}$ & $\begin{array}{c}0.08 \\
(0.06)\end{array}$ & $\begin{array}{c}0.11 \\
(0.07)\end{array}$ \\
\hline $\begin{array}{l}\text { Income Qua } \\
\text { Mean } \\
\text { (Std. Dev.) }\end{array}$ & $\begin{array}{c}0.27 \\
(0.15)\end{array}$ & $\begin{array}{c}0.34 \\
(0.15)\end{array}$ & $\begin{array}{c}0.18 \\
(0.09)\end{array}$ & $\begin{array}{c}0.06 \\
(0.08)\end{array}$ & $\begin{array}{c}0.08 \\
(0.07)\end{array}$ & $\begin{array}{c}0.09 \\
(0.05)\end{array}$ \\
\hline $\begin{array}{l}\text { Income Qua } \\
\text { Mean } \\
\text { (Std. Dev.) }\end{array}$ & $\begin{array}{c}0.30 \\
(0.15)\end{array}$ & $\begin{array}{c}0.35 \\
(0.15)\end{array}$ & $\begin{array}{c}0.15 \\
(0.08)\end{array}$ & $\begin{array}{c}0.05 \\
(0.06)\end{array}$ & $\begin{array}{c}0.09 \\
(0.07)\end{array}$ & $\begin{array}{c}0.07 \\
(0.04)\end{array}$ \\
\hline
\end{tabular}

Note: Data from the Consumer Expenditure Survey 1988-2000. See text for details. 


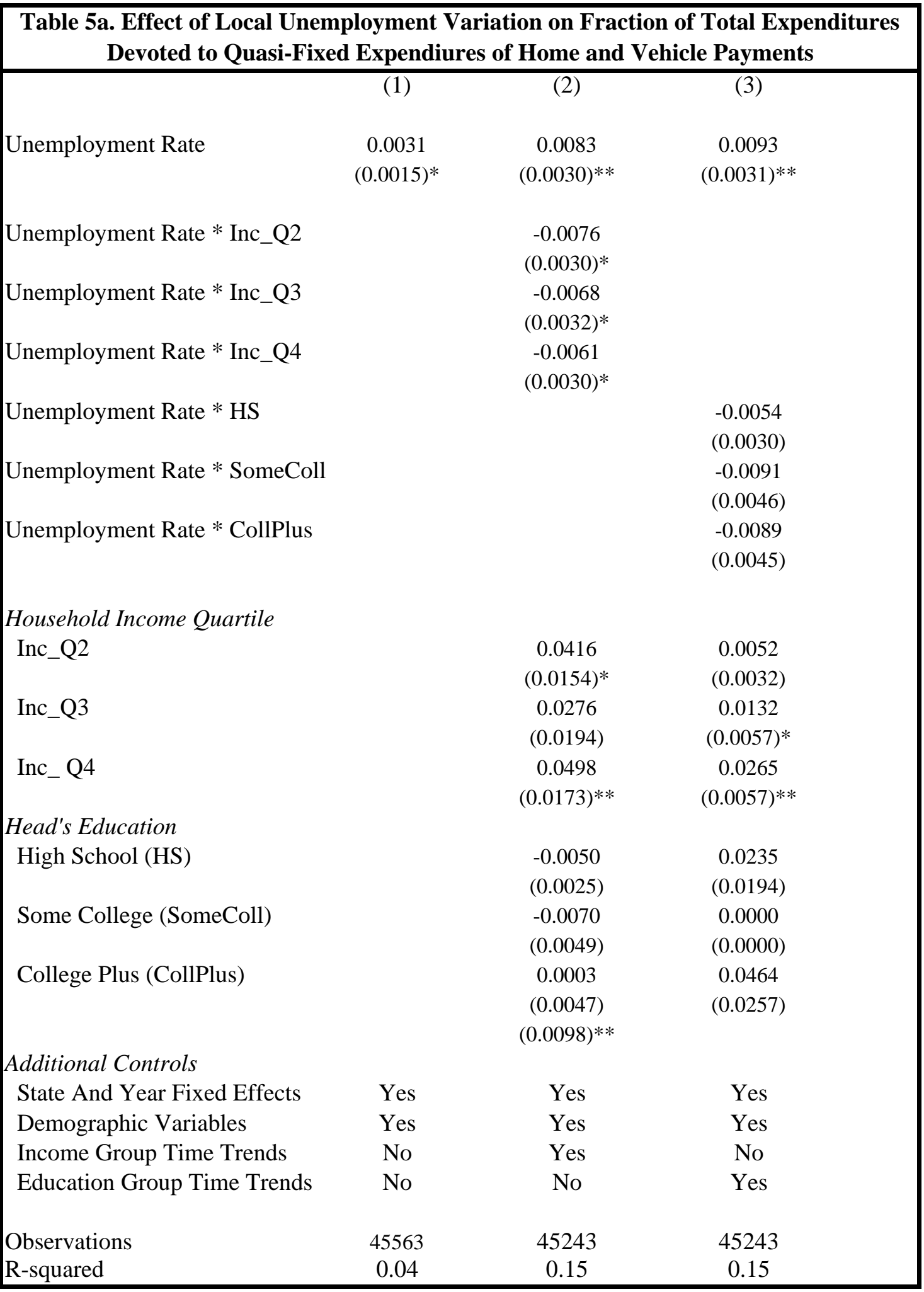

Notes: * significant at 5\%; ** significant at $1 \%$; The standard errors (in parentheses) allow for arbitrary correlation between observations from the same state over time; Demographic variables include age of the household head, family size, race of the household head, and marital status; See text for details 


\begin{tabular}{|c|c|c|}
\hline \multicolumn{3}{|c|}{$\begin{array}{c}\text { Table 5b. Effect of Local Unemployment on Fraction of Total Expenditures } \\
\text { Devoted to Quasi-Fixed Expendiures of Home and Vehicle Payments }\end{array}$} \\
\hline & (1) & $(2)$ \\
\hline \multirow[t]{2}{*}{ Unemployment Rate } & 0.0023 & 0.0025 \\
\hline & $(0.0018)$ & $(0.0016)$ \\
\hline \multirow[t]{2}{*}{ Unemployment Rate * Black } & 0.0050 & \\
\hline & $(0.0045)$ & \\
\hline \multirow[t]{2}{*}{ Unemployment Rate * Other-Race } & 0.0043 & \\
\hline & $(0.0038)$ & \\
\hline \multirow[t]{2}{*}{ Unemployment * Single Mother } & & 0.0106 \\
\hline & & $(0.0037)^{\star \star}$ \\
\hline \multicolumn{3}{|l|}{ Race } \\
\hline \multirow[t]{2}{*}{ Black } & -0.0085 & \\
\hline & $(0.0304)$ & \\
\hline \multirow[t]{2}{*}{ Other Race } & -0.0478 & \\
\hline & $(0.0258)$ & \\
\hline \multirow[t]{2}{*}{ Single Mother } & & -0.0435 \\
\hline & & $(0.0232)$ \\
\hline \multicolumn{3}{|l|}{ Additional Controls } \\
\hline State And Year Fixed Effects & Yes & Yes \\
\hline Demographic Variables & Yes & Yes \\
\hline Race-Specific Time Effects & Yes & No \\
\hline Single Mother Time Effects & No & Yes \\
\hline Observations & 45242 & 45242 \\
\hline R-squared & 0.15 & 0.31 \\
\hline
\end{tabular}

Notes: * significant at 5\%; ** significant at $1 \%$; The standard errors (in parentheses) allow for arbitrary correlation between observations from the same state over time; Demographic variables include age of the household head, family size, race of the household head, marital status, income group variables, and household head education group variables; See text for details 


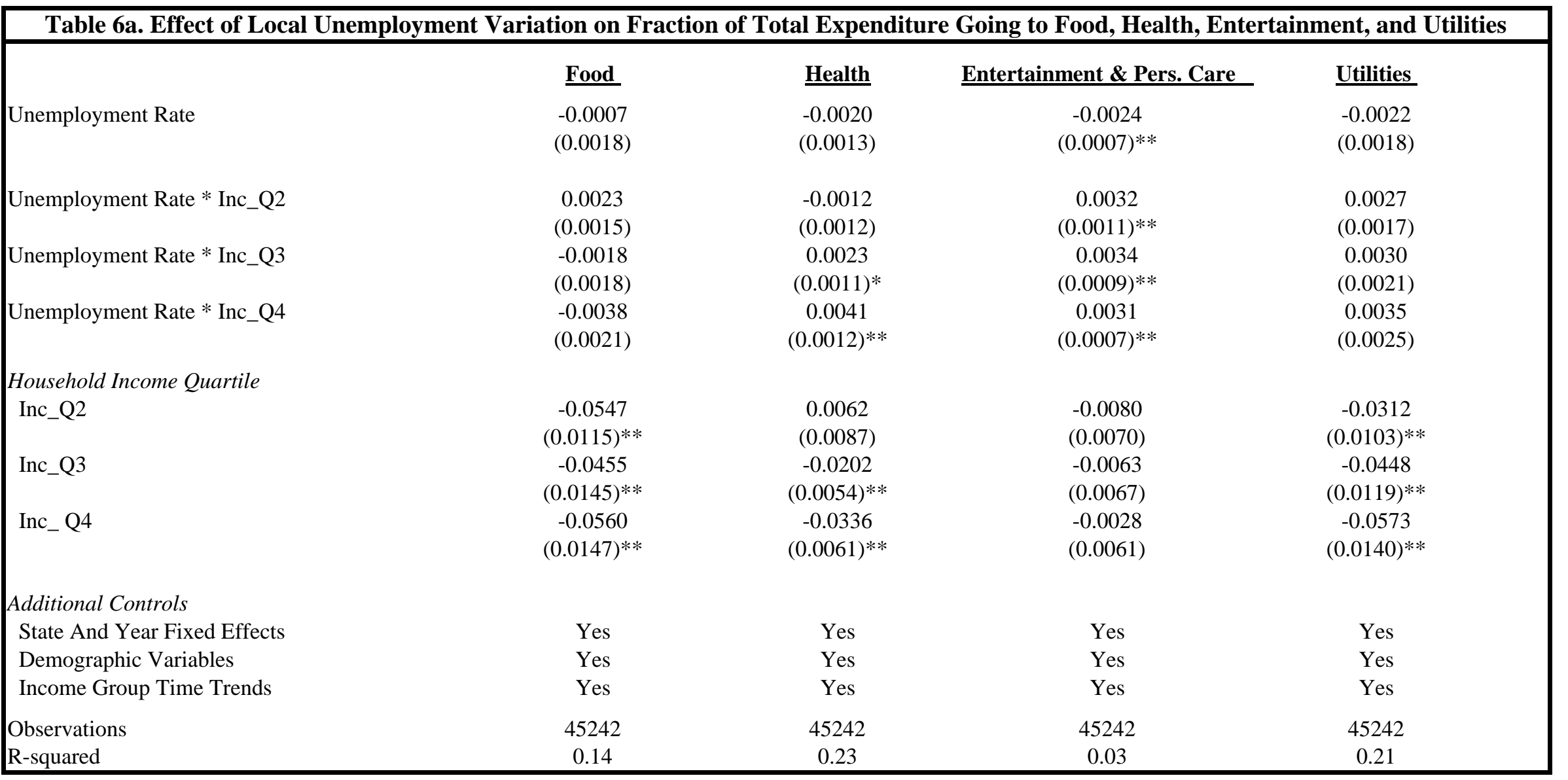

Notes: * significant at $5 \% ; * *$ significant at $1 \%$; The standard errors (in parentheses) allow for arbitrary correlation between observations from the same state over time; Demographic variables include age of the household head, family size, race of the household head, marital status, and household head education group variables; See text for details 
Table 6b. Effect of Local Unemployment Variation on Fraction of Total Expenditure Going to Food, Health, Entertainment, and Utilities

\begin{tabular}{|c|c|c|c|c|c|c|c|c|}
\hline \multirow[b]{2}{*}{ Unemployment Rate } & \multicolumn{2}{|c|}{ Food } & \multicolumn{2}{|c|}{ Health } & \multicolumn{2}{|c|}{ Ent \& Pers. Care } & \multicolumn{2}{|c|}{ Utilities } \\
\hline & $\begin{array}{l}-0.0014 \\
(0.0011)\end{array}$ & $\begin{array}{l}-0.0016 \\
(0.0010)\end{array}$ & $\begin{array}{c}-0.0002 \\
(0.0009)\end{array}$ & $\begin{array}{l}-0.0006 \\
(0.0009)\end{array}$ & $\begin{array}{l}-0.0002 \\
(0.0005)\end{array}$ & $\begin{array}{c}0.0003 \\
(0.0005)\end{array}$ & $\begin{array}{c}0.0008 \\
(0.0005)\end{array}$ & $\begin{array}{c}0.0003 \\
(0.0005)\end{array}$ \\
\hline U.R * Black & $\begin{array}{l}-0.0009 \\
(0.0031)\end{array}$ & & $\begin{array}{l}-0.0009 \\
(0.0011)\end{array}$ & & $\begin{array}{c}0.0015 \\
(0.0013)\end{array}$ & & $\begin{array}{c}-0.0040 \\
(0.0019)^{*}\end{array}$ & \\
\hline U.R. * Other-Race & $\begin{array}{c}-0.0020 \\
(0.0037)\end{array}$ & & $\begin{array}{l}-0.0021 \\
(0.0022)\end{array}$ & & $\begin{array}{c}0.0009 \\
(0.0011)\end{array}$ & & $\begin{array}{c}-0.0014 \\
(0.0015)\end{array}$ & \\
\hline U.R. * Single Mother & & $\begin{array}{c}-0.0011 \\
(0.0036)\end{array}$ & & $\begin{array}{c}0.0013 \\
(0.0012)\end{array}$ & & $\begin{array}{c}-0.0035 \\
(0.0016)^{*}\end{array}$ & & $\begin{array}{l}-0.0014 \\
(0.0020)\end{array}$ \\
\hline Black & $\begin{array}{c}0.0091 \\
(0.0171)\end{array}$ & & $\begin{array}{c}-0.0138 \\
(0.0070)\end{array}$ & & $\begin{array}{l}-0.0163 \\
(0.0085)\end{array}$ & & $\begin{array}{c}0.0444 \\
(0.0114)^{* *}\end{array}$ & \\
\hline Other Race & $\begin{array}{c}0.0259 \\
(0.0275)\end{array}$ & & $\begin{array}{c}0.0156 \\
(0.0176)\end{array}$ & & $\begin{array}{l}-0.0167 \\
(0.0083)\end{array}$ & & $\begin{array}{c}0.0027 \\
(0.0096)\end{array}$ & \\
\hline Single Mother & & $\begin{array}{c}0.0152 \\
(0.0194)\end{array}$ & & $\begin{array}{l}-0.0058 \\
(0.0096)\end{array}$ & & $\begin{array}{c}0.0101 \\
(0.0099)\end{array}$ & & $\begin{array}{c}0.0036 \\
(0.0130)\end{array}$ \\
\hline Additional Controls & & & & & & & & \\
\hline State And Year Fixed Effects & Yes & Yes & Yes & Yes & Yes & Yes & Yes & Yes \\
\hline Demographic Variables & Yes & Yes & Yes & Yes & Yes & Yes & Yes & Yes \\
\hline Race-Specific Time Effects & Yes & No & Yes & No & Yes & No & Yes & No \\
\hline Single Mother Time Effects & No & Yes & No & Yes & No & Yes & No & Yes \\
\hline Observations & 45242 & 45242 & 45242 & 45242 & 45242 & 45242 & 45242 & 45242 \\
\hline R-squared & 0.14 & 0.14 & 0.23 & 0.23 & 0.03 & 0.03 & 0.21 & 0.21 \\
\hline
\end{tabular}

Notes: * significant at $5 \%$; ** significant at $1 \%$; The standard errors (in parentheses) allow for arbitrary correlation between observations from the same state over time; Demographic variables include age of the household head, family size, race of the household head, marital status, income group variables, and household head education group variables; See text for details 


\begin{tabular}{|c|c|c|c|}
\hline \multicolumn{4}{|c|}{ Table 7a. Effect of Local Unemployment on Total Non-Collateralized Debt Owed } \\
\hline & $(1)$ & $(2)$ & (3) \\
\hline \multirow[t]{2}{*}{ Unemployment Rate } & -27.26 & -89.78 & -161.45 \\
\hline & $(59.42)$ & $(91.61)$ & $(123.86)$ \\
\hline \multirow[t]{2}{*}{ Unemployment Rate * Inc_Q2 } & & 1.35 & \\
\hline & & (82.03) & \\
\hline \multirow[t]{2}{*}{ Unemployment Rate * Inc_Q3 } & & -13.33 & \\
\hline & & (96.69) & \\
\hline \multirow[t]{2}{*}{ Unemployment Rate * Inc_Q4 } & & 252.54 & \\
\hline & & $(134.41)$ & \\
\hline \multirow[t]{2}{*}{ Unemployment Rate * HS } & & & 154.37 \\
\hline & & & $(113.87)$ \\
\hline \multirow[t]{2}{*}{ Unemployment Rate * SomeColl } & & & 195.20 \\
\hline & & & $(122.59)$ \\
\hline \multirow[t]{2}{*}{ Unemployment Rate * CollPlus } & & & 181.33 \\
\hline & & & $(165.01)$ \\
\hline \multicolumn{4}{|l|}{ Household Income Quartile } \\
\hline \multirow[t]{2}{*}{ Inc_Q2 } & & 71.68 & 266.19 \\
\hline & & (591.58) & $(100.22)^{*}$ \\
\hline \multirow[t]{2}{*}{ Inc_Q3 } & & 985.82 & $1,068.45$ \\
\hline & & $(607.38)$ & $(126.80)^{* *}$ \\
\hline \multirow[t]{2}{*}{ Inc_Q Q4 } & & $1,023.12$ & $1,851.83$ \\
\hline & & $(727.07)$ & $(227.67)^{* *}$ \\
\hline \multicolumn{4}{|l|}{ Head's Education } \\
\hline \multirow[t]{2}{*}{ High School (HS) } & & 134.96 & -829.01 \\
\hline & & $(112.14)$ & $(685.28)$ \\
\hline \multirow[t]{2}{*}{ Some College (SomeColl) } & & 810.37 & 0.0000 \\
\hline & & $(184.47)^{* *}$ & $(0.0000)$ \\
\hline \multirow[t]{2}{*}{ College Plus (CollPlus) } & & $1,414.56$ & 388.04 \\
\hline & & $(192.73)^{* *}$ & $(849.34)$ \\
\hline \multicolumn{4}{|l|}{ Additional Controls } \\
\hline State And Year Fixed Effects & Yes & Yes & Yes \\
\hline Demographic Variables & Yes & Yes & Yes \\
\hline Income Group Time Trends & No & Yes & Yes \\
\hline Observations & 45563 & 45242 & 45242 \\
\hline R-squared & 0.00 & 0.04 & 0.04 \\
\hline
\end{tabular}

Notes: * significant at 5\%; ** significant at $1 \%$; The standard errors (in parentheses) allow for arbitrary correlation between observations from the same state over time; Demographic variables include age of the household head, family size, race of the household head, marital status, and household head education group variables; See text for details 


\begin{tabular}{|c|c|c|}
\hline Table 7b. Effect of Local Unemp & otal Non-C & zed Debt \\
\hline & (1) & $(2)$ \\
\hline Unemployment Rate & $\begin{array}{l}-5.99 \\
(58.5)\end{array}$ & $\begin{array}{l}-12.63 \\
(56.97)\end{array}$ \\
\hline Unemployment Rate * Black & $\begin{array}{c}146.36 \\
(122.38)\end{array}$ & \\
\hline Unemployment Rate * Other-Race & $\begin{array}{l}-589.51 \\
(366.82)\end{array}$ & \\
\hline Unemployment * Single Mother & & $\begin{array}{l}-162.43 \\
(101.27)\end{array}$ \\
\hline Race & & \\
\hline Black & $\begin{array}{c}-1,318.81 \\
(722.14)\end{array}$ & \\
\hline Other Race & $\begin{array}{c}2,566.29 \\
(2,089.56)\end{array}$ & \\
\hline Single Mother & & $\begin{array}{c}-433.94 \\
(610.26)\end{array}$ \\
\hline Additional Controls & & \\
\hline State And Year Fixed Effects & Yes & Yes \\
\hline Demographic Variables & Yes & Yes \\
\hline Race-Specific Time Effects & Yes & No \\
\hline Single Mother Time Effects & No & Yes \\
\hline Observations & 45242 & 45242 \\
\hline R-squared & 0.04 & 0.04 \\
\hline
\end{tabular}

Notes: * significant at 5\%; ** significant at $1 \%$; The standard errors (in parentheses) allow for arbitrary correlation between observations from the same state over time; Demographic variables include age of the household head, family size, race of the household head, marital status, income group variables, and household head education group variables; See text for details 